•编者按・

\title{
森林动态大样地是生物多样性科学综合研究平台
}

\author{
马克平 ${ }^{*}$ \\ (中国科学院植物研究所植被与环境变化国家重点实验室, 北京 100093)
}

\section{Forest dynamics plot is a crosscutting research platform for biodiversity science}

\section{Keping Ma*}

State Key Laboratory of Vegetation and Environmental Change, Institute of Botany, Chinese Academy of Sciences, Beijing 100093

近年来, 物种共存或群落构建机制研究取得明 显进展, 成为群落生态学的标志性成果。大型森林 动态样地途径为此提供了独特的研究平台。中国森 林生物多样性监测网络(CForBio)自2004年开始建 立以来, 在各方面的共同努力下快速发展, 是全球 森林生物多样性研究最活跃的组成部分。已经建立 的大型森林监测样地18个(附录1), 1-5 ha的辅助样 地50多个, 比较好地代表了中国从寒温带到热带的 地带性森林类型, 样地面积达到538.6 ha, 监测木 本植物 227.9 万株, 隶属于 1,737 种。截至2017年 2 月 底, 基于CForBio大样地网络, 已经发表论文370多 篇(附录2), 其中SCI论文195篇, 在国内外同行中产 生了非常积极的影响。大型森林动态样地已经从建 立之初以植物群落生态学研究为主发展成多学科 交叉的生物多样性科学综合研究平台。以古田山亚 热带常绿阔叶林动态样地为例, 除24 ha主样地外, 还包括: (1)覆盖不同森林类型的13个1 ha辅助样地 和 27 个处于不同演替阶段的 $30 \mathrm{~m} \times 30 \mathrm{~m}$ 的卫星样 地; (2)将整个古田山国家级自然保护区分成 $1 \mathrm{~km} \times$ $1 \mathrm{~km}$ 的格子, 每个格子建立一个 $20 \mathrm{~m} \times 20 \mathrm{~m}$ 的卫 星样地, 同时布设一台红外相机(已连续监测近 3 年 时间); (3)选择主样地和辅助样地的3,000多株胸径5 $\mathrm{cm}$ 以上的树木布设生长环监测径级的年度变化; (4) 通过无人机搭载的激光雷达(LiDAR)、高光谱和多 光谱设备监测森林群落变化; (5)应用分子-组学方 法开展植物和微生物多样性研究; (6)正在建设森林 塔吊, 将覆盖1.3 ha林地。良好的综合研究平台促进
了物种共存机制研究的快速发展。

\section{1 植物功能性状研究的新进展}

由于取样难度大, 从植物功能性状角度研究森 林群落构建机制多以物种水平的平均功能性状为 依据(刘晓娟和马克平, 2015)。基于古田山森林动态 样地59种 822 株树的生长环季节动态监测和 12 种个 体功能性状数据, 通过构建包含种间竞争、生境过 滤和功能分化的结构方程模型, 揭示了植物生长的 差异是由发生在个体水平上的功能性状策略差异 直接造成的, 而竞争和生境过滤则是间接地通过塑 造不同的功能策略来影响生长动态(Liu et al, 2016)。该研究将个体水平的功能性状引入生长模 型, 从更小的尺度揭示了形成群落季节性动态的根 本原因。随着新一代测序技术的发展, 可以在没有 参考基因组的情况下对植物的转录组进行快速测 序、拼接和注释, 得到基因的序列和在特定环境下 的基因表达量。基于此, 转录组方法被引入古田山 亚热带常绿阔叶林物种共存机制的研究。Han等 (2017)通过对同种和异种邻居幼苗以及同源基因等 对目标幼苗的存活进行线性混合效应的拟合分析, 检测了同种和异种幼苗密度、同种和异种大树密度 以及同源基因的相似性对古田山24 ha样地的 85 种 木本植物幼苗存活的影响。结果表明与光相关的 15 个基因本体中有 3 个是与幼苗存活相关的。同时发 现光的光谱组成(光质)在幼苗对光合作用的响应方 面起重要作用, 使得具有相似光合作用能力的幼苗

\footnotetext{
* 通讯作者 Author for correspondence. E-mail: kpma@ibcas.ac.cn
} 
共存, 反映了环境的过滤作用。该研究展示了转录 组信息在群落构建研究中的应用前景。

\section{2 微生物生态学研究起点高发展快}

基于古田山大型森林样地的微生物生态学研 究取得了重要进展。大型森林动态样地的特色在于 胸径 $1 \mathrm{~cm}$ 以上的木本植物都测定空间位置和径级 大小, 并且每隔 5 年全部复查一次。对于微生物而 言, 有些木本植物是其宿主, 有些是其重要的生长 环境。如此翔实的植物分布数据, 对于微生物生态 学研究是十分难得的。Gao等(2013)通过分析外生菌 根菌与其宿主植物的关系, 发现二者在宿主植物属 级水平相关性最好, 而非种级。说明外生菌根菌的 专一性不是很强, 但具有较强的偏好性。土壤真菌 多样性在山脊和山谷不同, 而且与植物多样性相 关。在山脊, 腐生菌和病原菌多样性与植物丰富度 及土壤养分和湿度显著相关, 在山谷, 却与微地形 和甜楮(Castanopsis eyrei)的胸高断面积相关。外生 菌根菌多样性在山脊生境与甜槠的胸高断面积正 相关, 而在山谷生境则与全部木本植物的胸高断面 积正相关(Gao et al, 2017)。随着森林演替的进展, 外生菌根真菌群落构建机制发生变化。环境过滤在 所有的演替阶段都是群落构建的重要影响因素, 而 扩散限制则只在老龄林检测到(Gao et al, 2015)。谱 系关联性与从枝菌根菌和植物形成的互惠共生网络 相关。植物及其从枝菌根菌共生体的谱系保守性是亚 热带常绿阔叶林群落构建机制之一(Chen et al, 2017)。

\section{3 近地面遥感与大样地数据结合具良好前景}

近年来, 无人机在生态学中的应用发展很快, 为生态学研究由点到面的尺度拓展提供了有力支 持。在鼎湖山森林动态样地, 通过无人机搭载相机
拍摄高分辨率影像获取林冠参数(主要是林窗和林 冠高度), 将其与地面调查的大样地数据结合, 更好 地解析了森林植物多样性的空间分布格局(Zhang et $\mathrm{al}, 2016)$ 。LiDAR、高光谱和多光谱等设备在森林 动态样地及更大范围的应用, 使得森林三维可视化 与更多功能性状数据的自动获取成为可能, 为森林 群落构建机制研究展示了令人期待的光辉前景。

\section{4 中国森林动态样地网络向海外拓展}

中国科学院西双版纳热带植物园积极推动与 泰国的合作, 将中国的森林动态样地网络拓展到中 南半岛, 初步形成由 10 个大型森林样地组成的亚洲 热带雨林动态样地网络, 其中两个为亚高山常绿阔 叶林和针叶林样地(附录3)。监测的木本植物约 3,000 种 100 万株。该区域网络弥补了中国森林生物多样 性监测网络热带雨林代表性不充分的问题。

本期组织了生物多样性监测专题, 包括6篇文 章。有3篇文章介绍中国生物多样性监测与研究网 络(Sino BON)的3个专项网的设计框架和科学基础, 分别是林冠生物多样性监测(沈浩等, 2017)、兽类多 样性监测(肖治术等, 2017)和两栖爬行动物监测(李 成等, 2017)。两篇文章来自中国森林生物多样性监 测网络, 分别是关于玉龙雪山森林样地的物种组成 和群落结构(黄华等, 2017), 以及弄岗样地北热带喀 斯特季节性雨林调落物组分构成及时空动态特征 (郭屹立等, 2017)。本专题的另外一篇文章是关于湖 北七姊妹山亚热带常绿落叶阔叶混交林森林动态 样地的物种组成和群落结构(丁易等, 2017)。6篇文 章从不同角度展示了生物多样性监测与研究进展, 其中4篇基于森林动态样地研究。

文中引用的文献见附录4(http://www.biodiversity-science.net/fileup/PDF/2017113-4.pdf)

\section{附录 Supplementary Material}

附录1 中国森林生物多样性监测网络样地信息汇总

Appendix 1 Forest dynamics plots of Chinese Forest Biodiversity Monitoring Network (CForBio) http://www.biodiversity-science.net/fileup/PDF/2017113-1.pdf

附录2 中国森林生物多样性监测网络发表论文目录

Appendix 2 Publication list of Chinese Forest Biodiversity Monitoring Network (CForBio) http://www.biodiversity-science.net/fileup/PDF/2017113-2.pdf

附录 3 亚洲热带雨林动态样地网络

Appendix 3 Asia regional network for tropical rainforest dynamics plots http://www.biodiversity-science.net/fileup/PDF/2017113-3.pdf

附录4 参考文献(http://www.biodiversity-science.net/fileup/PDF/2017113-4.pdf) 
马克平. 森林动态大样地是生物多样性科学综合研究平台. 生物多样性, 2017, 25 (3): 227-228.

http://www.biodiversity-science.net/CN/10.17520/biods.2017113

附录1 中国森林生物多样性监测网络样地信息汇总

Appendix 1 Forest dynamics plots of Chinese Forest Biodiversity Monitoring Network (CForBio)

\begin{tabular}{|c|c|c|c|c|c|}
\hline 序号 & 样地名称 & 面积(ha) & 纬度(N) & 经度 $(\mathrm{E})$ & 负责单位 \\
\hline 1 & 大兴安岭兴安落叶松林样地 & 25 & $51.82^{\circ}$ & $122.99^{\circ}$ & 黑龙江省科学院自然与生态研究所 \\
\hline 2 & 小兴安岭丰林阔叶红松林样地 & 30 & $48.08^{\circ}$ & $129.12^{\circ}$ & 东北林业大学 \\
\hline 3 & 小兴安岭凉水典型阔叶红松林样地 & 9 & $47.18^{\circ}$ & $128.88^{\circ}$ & 东北林业大学 \\
\hline 4 & 小兴安岭谷地云冷杉林样地 & 9 & $47.2^{\circ}$ & $128.85^{\circ}$ & 东北林业大学 \\
\hline 5 & 穆棱东北红豆杉林样地 & 25 & $43.95^{\circ}$ & $130.07^{\circ}$ & 黑龙江省森林工程与环境研究所 \\
\hline 6 & 长白山阔叶红松林样地 & 25 & $42.38^{\circ}$ & $128.08^{\circ}$ & 中国科学院沈阳应用生态研究所 \\
\hline 7 & 东灵山暖温带落叶阔叶林样地 & 20 & $39.96^{\circ}$ & $115.43^{\circ}$ & 中国科学院植物研究所 \\
\hline 8 & 宝天曼暖温带落叶阔叶林样地 & 25 & $33.49^{\circ}$ & $111.94^{\circ}$ & 中国科学院植物研究所 \\
\hline 9 & 温带-亚热带过渡区秦岭落叶阔叶林样地 & 25 & $33.69^{\circ}$ & $107.82^{\circ}$ & 中国科学院武汉植物园 \\
\hline 10 & 八大公山中亚热带山地常绿落叶阔叶混交林样地 & 25 & $29.77^{\circ}$ & $110.09^{\circ}$ & 中国科学院武汉植物园 \\
\hline 11 & 天童亚热带常绿榈叶林样地 & 20 & $29.8^{\circ}$ & $121.8^{\circ}$ & 华东师范大学 \\
\hline 12 & 古田山亚热带常绿落叶林样地 & 24 & $29.25^{\circ}$ & $118.12^{\circ}$ & 中国科学院植物研究所 \\
\hline 13 & 玉龙雪山寒温性云冷杉林样地 & 25 & $27.14^{\circ}$ & $100.23^{\circ}$ & 中国科学院昆明植物研究所 \\
\hline 14 & 哀牢山亚热带常绿阔叶林样地 & 20 & $24.54^{\circ}$ & $101.03^{\circ}$ & 中国科学院西双版纳热带植物园 \\
\hline 15 & 木论喀斯特常绿落叶阔叶混交林样地 & 25 & $25.13^{\circ}$ & $108.00^{\circ}$ & 中国科学亚热带农业生态研究所 \\
\hline 16 & 鼎湖山南亚热带常绿榈叶林样地 & 20 & $23.10^{\circ}$ & $112.32^{\circ}$ & 中国科学院华南植物园 \\
\hline 17 & 弄岗喀斯特季节性雨林样地 & 15 & $22.43^{\circ}$ & $106.95^{\circ}$ & 中国科学院广西植物研究所 \\
\hline 18 & 西双版纳热带雨林样地 & 20 & $21.61^{\circ}$ & $101.57^{\circ}$ & 中国科学院西双版纳热带植物园 \\
\hline
\end{tabular}


马克平. 森林动态大样地是生物多样性科学综合研究平台. 生物多样性, 2017, 25 (3): 227-228.

http: //www.biodiversity-science.net/CN/10.17520/biods.2017113

\section{附录 2 中国森林生物多样性监测网络发表论文目录(2006-2016, 徐学红整理)}

Appendix 2 Publication list of Chinese Forest Biodiversity Monitoring Network (2006-2016, Collected by Xu Xuehong)

Anderson-Teixeira KJ, Davies SJ, Bennett AC, Gonzalez-Akre EB, Muller-Landau HC, Wright SJ, Salim KA, Zambrano AMA, Alonso A, Baltzer JL, Basset Y, Bourg NA, Broadbent EN, Brockelman WY, Bunyavejchewin S, Burslem DFRP, Butt N, Cao M, Cardenas D, Chuyong GB, Clay K, Cordell S, Dattaraja HS, Deng XB, Detto M, Du XJ, Duque A, Erikson DL, Ewango CEN, Fischer GA, Fletcher C, Foster RB, Giardina CP, Gilbert GS, Gunatilleke N, Gunatilleke S, Hao ZQ, Hargrove WW, Hart TB, Hau BCH, He FL, Hoffman FM, Howe RW, Hubbell SP, Inman-Narahari FM, Jansen PA, Jiang MX, Johnson DJ, Kanzaki M, Kassim AR, Kenfack D, Kibet S, Kinnaird MF, Korte L, Kral K, Kumar J, Larson AJ, Li YD, Li XK, Liu SR, Lum SKY, Lutz JA, Ma KP, Maddalena DM, Makana JR, Malhi Y, Marthews T, Serudin RM, McMahon SM, McShea WJ, Memiaghe HR, Mi XC, Mizuno T, Morecroft M, Myers JA, Novotny V, Oliveira de AA, Ong PS, Orwig DA, Ostertag R, Ouden den J, Parker GG, Phillips RP, Sack L, Sainge MN, Sang WG, Sri-ngernyuang K, Sukumar R, Sun IF, Sungpalee W, Suresh HS, Tan S, Thomas SC, Thomas DW, Thompson J, Turner BL, Uriarte M, Valencia R, Vallejo MI, Vicentini A, Vrška T, Wang XH, Wang XG, Weiblen G, Wolf A, Xu H, Yap S, Zimmerman J (2014) CTFS-ForestGEO: a worldwide network monitoring forests in an era of global change. Global Change Biology, 21, 528-549.

Bai XJ, Brenes-Arguedas T, Ye J, Wang XG, Lin F, Yuan ZQ, Shi S, Xing DL, Hao ZQ (2014) Dynamics of two multi-stemmed understory shrubs in two temperate forests. PLoS ONE, 9, e98200.

Bai XJ, Li BH, Zhang J, Wang LW, Yuan ZQ, Lin F, Hao ZQ (2010) Species composition, structure, and spatial distribution of shrubs in broad leaved Korean pine (Pinus koraiensis) mixed forest in Changbai Mountains. Chinese Journal of Applied Ecology, 21, 1899-1960. (in Chinese with English abstract) [白雪娇, 李步杭, 张健, 王利伟, 原作强, 萄菲, 郝占庆 (2010) 长白山 阔叶红松林灌木物种组成、结构和空间分布. 应用生态学报, 21, 1899-1960.]

Bai XJ, Queenborough SA, Wang XG, Zhang J, Li BH, Yuan ZQ, Xing DL, Lin F, Ye J, Hao ZQ (2012) Effects of local biotic neighbors and habitat heterogeneity on tree and shrub seedling survival in an old-growth temperate forest. Oecologia, 170, 755-765.

Bartlett MK, Zhang Y, Yang J, Kreidler N, Sun SW, Lin LX, Hu YH, Cao KF, Sack L (2016) Drought tolerance as a driver of tropical forest assembly: resolving spatial signatures for multiple processes. Ecology, 97, 503-514.

Bin Y, Lian JY, Wang ZM, Ye WH, Cao HL (2011) Tree mortality and recruitment in a subtropical broadleaved monsoon forest in South China. Journal of Tropical Forest Science, 23, 57-66.

Bin Y, Lin GJ, Li BH, Wu LF, Shen Y, Ye WH (2012) Seedling recruitment patterns in a 20 ha subtropical forest plot: hints for niche-based processes and negative density dependence. European Journal of Forest Research, 131, 453-461.

Bin Y, Spence J, Wu LF, Li BH, Hao ZQ, Ye WH, He FL (2016) Species-habitat associations and demographic rates of forest trees. Ecography, 39, 9-16.

Bin Y, Wang ZG, Wang ZM, Ye WH, Cao HL, Lian JY (2010) The effects of dispersal limitation and topographic heterogeneity on beta diversity and phylobetadiversity in a subtropical forest. Plant Ecology, 209, 237-256.

Bin Y, Ye WH, Cao HL, Huang ZL, Lian JY (2011) Seedling distribution in a subtropical evergreen broad-leaved forest plot in the Dinghu Mountain. Biodiversity Science, 19, 127-133. (in Chinese with English abstract) [宾粤，叶万辉，曹洪麟，黄忠良，练 琚愉 (2011) 鼎湖山南亚热带常绿阔叶林 20 公顷样地幼苗的分布. 生物多样性, 19, 127-133.]

Bin Y, Ye WH, Muller-Landau HC, Wu LF, Lian JY, Cao HL (2012) Unimodal tree size distributions possibly result from relatively strong conservatism in intermediate size classes. PLoS ONE, 7, e52596.

Cáceres MD, Legendre P, Valencia R, Cao M, Chang LW, Chuyong G, Condit R, Hao ZQ, Hsieh CF, Hubbell S, Kenfack D, Ma KP, Mi XC, Noor MNS, Rahman KA, Ren HB, Su SH, Sun IF, Thomas DC, Ye WH, He FL (2012) The variation of tree beta diversity across a global network of forest plots. Global Ecology and Biogeography, 21, 1191-1202.

Cai HY, Di XY, Chang SX, Jin GZ (2016) Stand density and species richness affect carbon storage and net primary productivity in early and late successional temperate forests differently. Ecological Research, 31, 525-533.

Cai HY, Di XY, Chang SX, Wang CK, Shi BK, Geng PF, Jin GZ (2016) Carbon storage, net primary production, and net ecosystem production in four major temperate forest types in northeastern China. Canadian Journal of Forest Research, 46, 143-156.

Cai HY, Di XY, Jin GZ (2014) Carbon density and production in valley spruce-fir forest in Xiaoxing'an Mountains, China. Chinese Journal of Applied Ecology, 25, 2794-2802. (in Chinese with English abstract) [蔡慧颖，邸雪颖，金光泽 (2014) 小兴安岭谷 地云冷杉林的碳密度与生产力. 应用生态学报, 25, 2794-2802.]

Cai HY, Di XY, Jin GZ (2015) Carbon density of coarse woody debris in a spruce-fir valley forest in Xiaoxing'an Mountains, China. Acta Ecologica Sinica, 35, 8194-8201. (in Chinese with English abstract) [蔡慧颖, 邸雪颖, 金光泽 (2015) 小兴安岭谷地云 冷杉林粗木质残体碳密度特征. 生态学报, 35, 8194-8201.]

Cao K, Rao MD, Yu JZ, Liu XJ, Mi XC, Chen JH (2013) The phylogenetic signal of functional traits and their effects on community structure in an evergreen broad-leaved forest. Biodiversity Science, 21, 564-571. (in Chinese with English abstract) [曹科, 饶米德, 余建中, 刘晓娟, 米湘成, 陈建华 (2013) 古田山木本植物功能性状的系统发育信号及其对群落结构的 
影响. 生物多样性, 21, 564-571.]

Chen GK, Kéry M, Plattner M, Ma KP, Gardner B (2013) Imperfect detection is the rule rather than the exception in plant distribution studies. Journal of Ecology, 101, 183-191.

Chen GK, KéryM, Zhang JL, Ma KP (2009) Factors affecting detection probability in plant distribution studies. Journal of Ecology, 97, 1383-1389.

Chen J, Rui YC, Zhou X, Ye WH, Liu W (2016) Determinants of the biodiversity patterns of ammonia-oxidizing archaea community in two contrasting forest stands. Journal of Soil and Sediments, 16, 878-888.

Chen JL, Jin GZ, Zhao FX (2010) Litter decomposition and nutrient dynamics at different succession stages of typical mixed broadleaved-Korean pine forest in Xiaoxing'an Mountains, China. Chinese Journal of Applied Ecology, 21, 2209-2216. (in Chinese with English abstract) [陈金玲, 金光泽, 赵风霞 (2010) 小兴安岭典型阔叶红松林不同演替阶段调落物分解及养 分变化. 应用生态学报, 21, 2209-2216.]

Chen JY, Bi LZ, Song GH, Zhang W, Wang QB, Liu YY, Jin GZ (2016) Characteristics of woody debris in broadleaved-Korean pine forest plot in Fenglin National Nature Reserve in Xiaoxing'anling Moutains, China. Journal of Nanjing Forestry University (Natural Sciences Edition), 40(6), 76-84. (in Chinese with English abstract) [陈镜园，毕连柱，宋国华，张伟，王全波，刘妍妍， 金光泽 (2016) 小兴安岭丰林阔叶红松林木质物残体的穴量特征分析. 南京林业大学学报(自然科学版), 40(6), 76-84.]

Chen L, Mi XC, Comita L, Zhang LW, Ren HB, Ma KP (2010) Community-level consequences of density dependence and habitat association in a subtropical broad-leaved forest. Ecology Letters, 13, 695-704.

Chen TB, Sung YH, Chan PLB, Meng YJ, Wan PH (2013) Influence of surface water availability on mammal distributions in Nonggang National Nature Reserve, Guangxi, China. Zoological Research, 34, 145-151. (in Chinese with English abstract) [陈 天波, 宋亦希, 陈辈乐, 蒙渊君, 温柏豪 (2013) 利用红外线相机监测地表水对广西弄岗国家级自然保护区兽类分布的影 响. 动物学研究, 34, 145-151.]

Chen XR, Chen YY, Luo ZR, Ding BY (2013) A 5-year mid-mountain subtropical evergreen broadleaved forest study in Baishanzu, east China. Journal of Zhejiang A \& F University, 30, 821-829. [陈小荣, 陈圆圆, 骆争荣, 丁炳扬 (2013) 百山祖中山中亚 热带常绿阔叶林群落 5 年动态特征. 浙江农林大学学报, 30, 821-829.]

Chen Y (2009) Detection effect of phylogenetic diversity on seedling mortality in an evergreen broad-leaved forest in China. Chinese Journal of Plant Ecology, 33, 1084-1089. (in Chinese with English abstract) [陈英 (2009) 常绿阔叶林谱系多样性对 幼苗存活率的影响. 植物生态学报, 33, 1084-1089]

Chen Y, Yuan ZL, Li PK, Cao RF, Jia HR, Ye YZ (2016) Effects of environment and space on species turnover of woody plants across multiple forest dynamic plots in East Asia. Frontiers in Plant Science, 7, 1533.

Chen Y, Yuan ZL, Ren SY, Wei BL, Jia HR, Ye YZ (2014) Correlation analysis of soil and species of different life forms in Baotianman Nature Reserve. Chinese Science Bulletin, 59, 2367-2376. (in Chinese with English abstract) [陈云，袁志良，任思 远，韦博良，贾宏汝，叶永忠 (2014) 宝天曼自然保护区不同生活型物种与土壤相关性分析. 科学通报, 59, 2367-2376.]

Chen Z, Zhu H (2009) Investigation on the flora of herbaceous plants under the tropical rain forest of Xishuangbanna. Journal of Northwest Forestry University, 4(1), 11-15. (in Chinese with English abstract) [陈征, 朱华 (2009) 西双版纳热带雨林草本植 物区系初步分析. 西北林学院学报, 4(1), 11-15.]

Cheng JJ, Mi XC, Ma KP, Zhang JT (2011) Responses of species-abundance distribution to varying sampling scales in a subtropical broad-leaved forest. Biodiversity Science, 19, 168-177. (in Chinese with English abstract) [程佳佳，米湘成，马克 平，张金屯 (2011) 亚热带常绿阔叶林群落物种多度分布格局对取样尺度的响应. 生物多样性, 19, 168-177.]

Cheng JJ, Mi XC, Zhang JT, Ma KP (2012) Separating the effect of mechanisms shaping species-abundance distributions at multiple scales in a subtropical forest. Oikos, 121, 236-244.

Chisholm RA, Muller-Landau HC, Rahman KA, Bebber DP, Bin Y, Bohlman SA, Bourg NA, Brinks J, Bunyavejchewin S, Butt N, Cao HL, Cao M, Cardenas D, Chang LW, Chiang JM, Chuyong G, Condit R, Dattaraja HS, Davies S, Duque A, Fletcher C, Gunatilleke N, Gunatilleke S, Hao ZQ, Harrison RD, Howe R, Hsieh CF, Hubbell SP, Itoh A, Kenfack D, Kiratiprayoon S, Larson AJ, Lian JY, Lin DM, Liu HF, Lutz JA, Ma KP, Malhi Y, McMahon S, McShea W, Meegaskumbura M, Razman SM, Morecroft MD, Nytch CJ, Oliveira A, Parker GG, Pulla S, Punchi-Manage R, Romero-Saltos H, Sang WG, Schurman J, Su SH, Sukumar R, Sun IF, Suresh HS, Sylvester T, Thomas DC, Thomas S, Thompson J, Valencia R, Wolf A, Yap S, Ye WH, Yuan ZQ, Zimmerman JK (2013) Scale-dependent relationships between tree species richness and ecosystem function in forests. Journal of Ecology, 101, 1214-1224.

Cui FX, Song JF, Zhu DG, Li JB, Qi ZY, Shan L, Ni HW (2016) Effects of oxalic acid on physiological-biochemical traits of cold temperate Larix gmelinii seedlings under soil nutrient deficiency. International Conference on Biological Sciences and Technology (BST 2016), 331-336.

Diao YF, Jin GZ, Tian SY, Liu YK, Liu YL, Han LD, Li YH (2016) Species composition and community structure of a Taxus cuspidate forest in Muling Nature Reserve of Heilongjiang Province, China. Scientia Silvae Sinicae, 52(5), 26-36. (in Chinese with English abstract) [ᄀ云飞, 金光泽, 田松岩, 刘延坤, 刘玉龙, 韩丽冬, 李云红 (2016) 黑龙江省穆棱东北红豆杉物种 组成与群落结构. 林业科学, 52(5), 26-36.]

Ding J, Wu Q, Yan H, Zhang SR (2011) Effects of topographic variations and soil characteristics on plant functional traits in a subtropical evergreen broad-leaved forest. Biodiversity Science, 19, 158-167. (in Chinese with English abstract) [丁佳, 吴茜, 


\section{间慧，张守仁 (2011) 地形和土壤特性对亚热带常绿阔叶林内植物功能性状的影响. 生物多样性, 19, 158-167.]}

Dong L, Wang ZF, Zhu P, Ye WH (2010) Isolation and characterization of microsatellite loci in Castanopsis fissa in lower subtropical China. Silvae Genetica, 299-300.

Du YJ, Ma KP (2012) Advancements and prospects in forest seed rain studies. Biodiversity Science, 20, 94-107. (in Chinese with English abstract) [杜彦君, 马克平 (2012) 森林种子雨研究进展与展望. 生物多样性, 20, 94-107.]

Du YJ, Ma KP (2012) Temporal and spatial variation of seedfall in a broad-leaved evergreen forest in Gutianshan Nature Reserve of Zhejiang Province, China. Chinese Journal of Plant Ecology, 36, 717-728. (in Chinese with English abstract) [杜彦君，马克平 (2012) 浙江古田山自然保护区常绿阔叶林种子雨的时空变异. 植物生态学报, 36, 717-728.]

Du YJ, Mao LF, Queenborough SA, Freckleton RP, Chen B, Ma KP (2015) Phylogenetic constraints and trait correlates of flowering phenology in the angiosperm flora of China. Global Ecology and Biogeography, 24, 928-938.

Du YJ, Mi XC, Liu XJ, Ma KP (2012) The effects of ice storm on seed rain and seed limitation in an evergreen broad-leaved forest in east China. Acta Oecologica, 39, 87-93.

Du YJ, Mi XC, Ma KP (2012) Comparison of seed rain and seed limitation between community understory and gaps in a subtropical evergreen forest. Acta Oecologica, 1-9.

Du YJ, Mi XC, Ren HB, Liu XJ, Chen L, Fang T, Zhu Y, Ma KP (2009) Seed dispersal phenology and dispersal syndromes in a subtropical broad-leaved forest of China. Forest Ecology and Management, 258, 1147-1152.

Fang S, Yuan ZQ, Lin F, Ye J, Hao ZQ, Wang XG (2014) Functional and phylogenetic structures of woody plants in broad-leaved Korean pine mixed forest in Changbai Mountains, Jilin, China. Chinese Science Bulletin, 59, 2342-2348. (in Chinese with English abstract) [房帅, 原作强, 萄菲, 叶吉, 郝占庆, 王绪高 (2014) 长白山阔叶红松林木本植物系统发育与功能性状 结构. 科学通报, 59, 2342-2348.]

Fang XB, Qiu X, Zhou YL, Yang LY, Zhao Y, Zheng WH, Liu JS (2015) Acoustic characteristics of advertisement calls in Babina adenopleura. Asian Herpetological Research, 6, 220-228.

Fang XF, Shen GC, Yang QS, Liu HM, Ma ZP, Deane DC, Wang XH. (2017) Habitat heterogeneity explains mosaics of evergreen and deciduous trees at local-scales in a subtropical evergreen broad-leaved forest. Journal of Vegetation Science, 28, 379-388.

Fang XF, Yang QS, Liu HM, Ma ZP, Dong S, Cao Y, Yuan MJ, Fei XY, Sun XY, Wang XH (2016) Distribution of species abundance of evergreen and deciduous woody plants in the evergreen broad-leaved forests at Tiantong, Zhejiang. Biodiversity Science, 26, 629-638. (in Chinese with English abstract) [方晓峰，杨庆松，刘何铭，马遵平，董舒，曹烨，袁铭晈，费希旸， 王希华 (2016) 天童常绿阔叶林中常绿与落叶物种的物种多度分布格局. 生物多样性, 26, 629-638.]

Feng G, Mi XC, Bøcher PK, Mao LF, Brody S, Cao M, Ye WH, Hao ZQ, Gong HD, Zhang YT, Zhao XH, Jin GZ, Ma KP, Svenning JC (2014) Relative roles of local disturbance, current climate and palaeoclimate in determining phylogenetic and functional diversity in Chinese forests. Biogeosciences, 11, 1361-1370.

Feng G, Mi XC, Eiserhardt WL, Jin GZ, Sang WG, Lu ZJ, Wang XH, Li XK, Li BH, Sun IF, Ma KP, Svenning JC (2015) Assembly of forest communities across East Asia-insights from phylogenetic community structure and species pool scaling. Scientific Reports, 5, 9337.

Feng G, Mi XC, Yan H, Li FY, Svenning JC, Ma KP (2016) CForBio: a network monitoring Chinese forest biodiversity. Science Bulletin, 61, 1163-1170.

Feng G, Svenning JC, Mi XC, Jia Q, Rao MD, Ren HB, Bebber DP, Ma KP (2014) Anthropogenic disturbance shapes phylogenetic and functional tree community structure in a subtropical forest. Forest Ecology and Management, 313, 188-198.

Feng G, Zhang JL, Pei NC, Rao MD, Mi XC, Ren HB, Ma KP (2012) Comparison of phylobetadiversity indices based on community data from Gutianshan forest plot. Chinese Science Bulletin, 57, 623-630.

Gao C, Shi NN, Liu YX, Peay KG, Zheng Y, Ding Q, Mi XC, Ma KP, Wubet T, Buscot F, Guo LD (2013) Host plant genus-level diversity is the best predictor of ectomycorrhizal fungal diversity in a Chinese subtropical forest. Molecular Ecology, 22, 3403-3414.

Gao C, Zhang Y, Shi NN, Zheng Y, Chen L, Wubet T, Bruelheide H, Both S, Buscot F, Ding Q, Erfmeier A, Kühn P, Nadrowski K, Scholten T, Guo LD (2015) Community assembly of ectomycorrhizal fungi along a subtropical secondary forest succession. New Phytologist, 205, 771-785.

Gao WF, Shi BK, Jin GZ (2016) Effect of simulated nitrogen deposition on soil respiration in the typical mixed broadleaved-Korean pine forest. Journal of Nanjing Forestry University (Natural Science Edition), 40(1), 8-14. (in Chinese with English abstract) [高伟峰, 史宝库, 金光泽 (2016) 模拟氮沉降对典型阔叶红松林土壤呼吸的影响. 南京林业大学学报(自 然科学版), 40(1), 8-14.]

Geng PF, Jin GZ (2016) Spatial and temporal patterns of fine root biomass in four forest types in Xiaoxing'an Mountains. Scientia Silvae Sinicae, 52, 140-148. (in Chinese with English abstract) [耿鹏飞, 金光泽 (2016) 小兴安岭 4 种森林类型细根生物 量的时空格局. 林业科学, 52, 140-148.]

Gong GQ, Chen JM, Mi XC, Chen SW, Fang T (2007) Habitat associations of wood species in the Gutianshan subtropical broad-leaved evergreen forest. Science of Soil and Water Conservation, 5(3), 79-83. (in Chinese with English abstract) [宫贵权, 程积民，米湘成，陈声文，方腾 (2007) 古田山常绿阔叶林木本植物与生境的相关性. 中国水土保持科学, 5(3), 79-83.]

Gong GQ, Huang ZL, Huang JX, Ye WH, Cao HL, Lian JY, Lin GJ (2011) How individual species structure the community in 
Dinghushan 20 ha forest plot? Ecology and Environmental Sciences, 20, 991-995. (in Chinese with English abstract) [宫贵权， 黄忠良, 黄建雄, 叶万辉, 曹洪麟, 练琚愉, 林国俊 (2011) 鼎湖山 20 公顷森林样地单个物种对群落的构建. 生态环境 学报, 20, 991-995.]

Guo Y, Wang YQ, Chen L, Mi XC, Ren HB, Chen SW, Chen JH (2016) Comparing tree seedling composition and distribution patterns under different sampling intensities in the 24 ha Gutianshan forest dynamics plot. Biodiversity Science, 24, 1093-1104. (in Chinese with English abstract) [郭印，王云泉，陈否，米湘成，任海保，陈声文，陈建华 (2016) 不同取样强 度下古田山木本植物幼苗组成及其分布格局比较. 生物多样性, 24, 1093-1104.]

Guo YL, Lu JM, Franklin S, Wang QG, Xu YZ, Zhang KH, Bao DC, Qiao XJ, Huang HD, Lu ZJ, Jiang MX (2013) Spatial distribution of tree species in a species-rich subtropical mountain forest in central China. Canadian Journal of Forest Research, 43, 826-835.

Guo YL, Lu ZJ, Wang QG, Xu YZ, Zhang KH, Bao DC, Qiao XJ, Huang HD, Jiang MX (2015) Detecting density dependence from spatial patterns in a heterogeneous subtropical forest of central China. Canadian Journal of Forest Research, 45, 710-720.

Guo YL, Wang B, Mallik AU, Huang FZ, Xiang WS, Ding T, Wen SJ, Lu SH, Li DX, He YL, Li XK (2016) Topographic species-habitat associations of tree species in a heterogeneous tropical karst seasonal rain forest, China. Journal of Plant Ecology, DOI: $10.1093 /$ jpe/rtw057.

Guo YL, Wang B, Xiang WS, Ding T, Lu SH, Huang FZ, Li DX, Wen SJ, He YL, Li XK (2015) Density-dependent effects of tree species in a 15 ha seasonal rain forest plot in northern tropical karst in Nonggang, Guangxi, southern China. Chinese Science Bulletin, 60, 1602-1611. (in Chinese with English abstract) [郭屹立，王斌，向悟生，丁涛，陆树华，黄甫昭，李冬兴，文淑均， 何运林, 李先琨 (2015) 弄岗喀斯特季节性雨林 15 ha 样地密度制约效应分析. 科学通报, 60, 1602-1611.]

Guo YL, Wang B, Xiang WS, Ding T, Lu SH, Huang FZ, Wen SJ, Li DX, Li XK (2016) Spatial distribution and habitat-association of snags in the tropical karst seasonal rainforest of Southwest Guangxi, China. Guihaia, 36, 154-161. (in Chinese with English abstract) [郭屹立, 王斌，向悟生，丁涛，陆树华，黄甫昭，文淑均，李冬兴，李先琨 (2016) 桂西南喀斯特季节性雨林枯立 木的空间格局及生境关联性分析. 广西植物, 36, 154-161.]

Guo YL, Wang B, Xiang WS, Ding T, Lu SH, Huang FZ, Wen SJ, Li DX, He YL, Li XK (2016) Responses of spatial pattern of woody plants' basal area to topographic factors in a tropical karst seasonal rainforest in Nonggang, Guangxi, southern China. Biodiversity Science, 24, 30-39. (in Chinese with English abstract) [郭屹立，王斌，向悟生，丁涛，陆树华，黄甫昭，文淑均， 李冬兴，何运林，李先琨 (2016) 喀斯特季节性雨林木本植物胸高断面积分布格局及其对地形因子的响应. 生物多样性, 24, 30-39.]

Guo YL, Wang B, Xiang WS, Ding T, Lu SH, Huang YS, Huang FZ, Li DX, Li XK (2015) Spatial distribution of tree species in a tropical karst seasonal rainforest in Nonggang, Guangxi, southern China. Biodiversity Science, 23, 183-191. (in Chinese with English abstract) [郭屹立, 王斌, 向悟生, 丁涛, 陆树华, 黄俞淞, 黄甫昭, 李冬兴, 李先琨 (2015) 广西弄岗北热带喀斯 特季节性雨林监测样地种群空间点格局分析. 生物多样性, 23, 183-191.]

Guo YL, Wang B, Xiang WS, Ding T, Lu SH, Wen SJ, Huang FZ, Li DX, Li XK (2015) Sprouting characteristics of tree species in $15-\mathrm{hm}^{2}$ plot of northern tropical karst seasonal rain forest in Nonggang, Guangxi, southern China. Chinese Journal of Ecology, 34, 955-961. (in Chinese with English abstract) [郭屹立, 王斌, 向悟生, 丁涛, 陆树华, 文淑均, 黄甫昭, 李冬兴, 李先琨 (2015) 弄岗北热带喀斯特季节性雨林 $15 \mathrm{hm}^{2}$ 样地木本植物萌生特征. 生态学杂志, 34, 955-961.]

Han BC, Wei W, Mi XC, Ma KP (2016) De novo sequencing and comparative analysis of Schima superb seedlings to explore the response to drought stress. PLoS ONE, 11, e0166975.

Han MG, Shi BK, Jin GZ (2016) Temporal variations of soil respiration at multiple timescales in a spruce-fir valley forest, northeastern China. Journal of Soils and Sediments, 16, 2385-2394.

Hao ZQ, Li BH, Zhang J, Wang XG, Ye J, Yao XL (2008) Broad-leaved Korean pine (Pinus koraiensis) mixed forest plot in Changbaishan (CBS) of China: community composition and structure. Journal of Plant Ecology (Chinese Version), 32, 238-250. (in Chinese with English abstract) [郝占庆, 李步杭, 张健, 王绪高, 叶吉, 姚晓琳 (2008) 长白山阔叶红松林样地(CBS): 群落组成与结构. 植物生态学报, 32, 238-250.]

Hao ZQ, Zhang J, Li BH, Ye J, Wang XG, Yao XL (2008) Natural secondary poplar-birch forest in Changbai Mountain: species composition and community structure. Journal of Plant Ecology (Chinese Version), 32, 251-261. (in Chinese with English abstract) [郝占庆, 张健, 李步杭, 叶吉, 王绪高, 姚晓琳 (2008) 长白山次生杨桦林样地: 物种组成与群落结构. 植物生 态学报, 32, 251-261.]

Hao ZQ, Zhang J, Song B, Ye J, Li BH (2007) Vertical structure and spatial associations of dominant tree species in an old-growth temperate forest. Forest Ecology and Management, 252, 1-11.

He J, Li XY, Gao DD, Zhu P, Wang ZF, Wang ZM, Ye WH, Cao HL (2013) Topographic effects on fine-scale spatial genetic structure in Castanopsis chinensis Hance (Fagaceae). Plant Species Biology, 28, 87-93.

He ZY, Tang Y, Deng XB, Cao M (2013) Buttress trees in a 20-hectare tropical dipterocarp rainforest in Xishuangbanna, SW China. Journal of Plant Ecology, 6, 187-192.

Hu XL, Chang-Yang CH, Mi XC, Du YJ, Chang ZY (2015) Influence of climate, phylogeny, and functional traits on flowering phenology in a subtropical evergreen broad-leaved forest, East China. Biodiversity Science, 23, 601-609. (in Chinese with English abstract) [胡小丽, 张杨家豪, 米湘成, 杜彦君, 常朝阳 (2015) 浙江古田山亚热带常绿阔叶林开花物候: 气候因 


\section{素、系统发育关系和功能性状的影响. 生物多样性, 23, 601-609.]}

Hu YH, Cao M, Lin LX (2010) Dynamics of tree species composition and community structure of a tropical seasonal rain forest in Xishuangbanna, Southwest China. Acta Ecologica Sinica, 30, 949-957. (in Chinese with English abstract) [胡跃华, 曹敏, 林露 湘 (2010) 西双版纳热带季节雨林的树种组成和群落结构动态. 生态学报, 30, 949-957.]

Hu YH, Kitching LR, Lan GY, Zhang JL, Sha LQ, Cao M (2014) Size-class effect contributes to tree species assembly through influencing dispersal in tropical forests. PLoS ONE, 9, e108450.

Hu YH, Lan GY, Sha LQ, Cao M, Tang Y, Li YD, Xu DP (2012) Strong neutral spatial effects shape tree species distributions across life stages at multiple scales. PLoS ONE, 7, e38247.

Hu YH, Sha LQ, Blanchet FG, Zhang JL, Tang Y, Lan GY, Cao M (2012) Dominant species and dispersal limitation regulate tree species distributions in a 20-ha plot in Xishuangbanna, southwest China. Oikos, 952-960.

Hu ZH, Qian HY, Yu MJ (2009) The niche of dominant species populations in Castanopsis eyrei forest in Gutian Mountain National Nature Reserve. Acta Ecologica Sinica, 29, 3670-3677. (in Chinese with English abstract) [胡正华, 钱海源, 于明坚 (2009) 古田山国家级自然保护区甜槠林优势种种群生态位. 生态学报, 29, 3670-3677.]

Huang FZ, Ding T, Li XK, Guo YL, Wang B, Xiang WS, Wen SJ, Li DX, He YL (2016) Species diversity of associations changing along with relative altitude in the northern tropical karst seasonal rainforest in Nonggang plot. Acta Ecologica Sinica, 36, 4509-4517. (in Chinese with English abstract) [黄甫昭, 丁涛, 李先琨, 郭屹立, 王斌, 向悟生, 文淑均, 李冬兴, 何运林 (2016) 弄岗喀斯特季节性雨林不同群丛物种多样性随海拔的变化. 生态学报, 36, 4509-4517.]

Huang FZ, Ding T, Li XK, Guo YL, Wang B, Xiang WS, Wen SJ, Li DX, He YL (2016) Species diversity for various associations along an altitudinal gradient in the karst seasonal rainforest in Nonggang. Acta Ecologica Sinica, 26, 4509-4517. (in Chinese with English abstract) [黄甫昭, 丁涛, 李先琨, 郭屹立, 王斌, 向悟生, 文淑均, 李冬兴, 何运林 (2016) 弄岗喀斯特季节 性雨林不同群从物种多样性随海拔的变化. 生态学报, 26, 4509-4517.]

Huang FZ, Wang B, Ding T, Xiang WS, Li XK, Zhou AP (2014) Numerical classification of associations in a northern tropical karst seasonal rain forest and the relationships of these associations with environmental factors. Biodiversity Science, 22, 157-166. (in Chinese with English abstract) [黄甫昭, 王斌, 丁涛, 向悟生, 李先琨, 周爱萍 (2014) 弄岗北热带喀斯特季节性雨林群丛 数量分类及与环境的关系. 生物多样性, 22, 157-166.]

Huang GM, Hong L, Ye WH, Shen H, Cao HL, Wei X (2009) Isolation and characterization of polymorphic microsatellite loci in Castanopsis chinensis Hance (Fagaceae). Conservation Genetics, 10, 1069-1071.

Huang JX, Mi XC, Ma KP (2011) A genome evolution-based framework for measures of originality for clades. Journal of Theoretical Biology, 276, 99-105.

Huang JX, Ye WH, Lian JY, Cao HL (2014) Detecting the influence of phylogenetic structure, environmental factors and PCNM factors in population dynamics in a subtropical forest community in Guangdong, China. Chinese Science Bulletin, 59, 3471-3478. (in Chinese with English abstract) [黄建雄, 叶万辉, 练琚愉, 曹洪麟 (2014) 谱系结构、环境因子及空间因子对 群落动态变化的影响. 科学通报, 59, 3471-3478.]

Huang JX, Zhang J, Shen Y, Lian JY, Cao HL, Ye WH, Wu LF, Bin Y (2014) Different relationships between temporal phylogenetic turnover and phylogenetic similarity and in two forests were detected by a new null model. PLoS ONE, 9, e95703.

Huang JX, Zheng FY, Mi XC (2010) Influence of environmental factors on phylogenetic structure at multiple spatial scales in an evergreen broad-leaved forest of China. Chinese Journal of Plant Ecology, 34, 309-315. (in Chinese with English abstract) [黄建 雄, 郑风英, 米湘成 (2010) 不同尺度上环境因子对常绿阔叶林群落的谱系结构的影响. 植物生态学报, 34, 309-315.]

Huang XC, Ci XQ, Conran JG, Li J (2015) Application of DNA barcodes in Asian tropical trees-a case study from Xishuangbanna Nature Reserve, Southwest China. PLoS ONE, 10, e0129295.

Huang YS, Liu SY, Peng RC, Xu WB (2012) A newly recorded species of Phaius (Orchidaceae) from China. Guihaia, 32, 143-145. (in Chinese with English abstract) [黄俞㳂, 刘㖇源, 彭日成, 许为斌 (2012) 中国鹤顶兰属(兰科)一新记录种. 广西植物, 32, 143-145.]

Huang YS, Lu MX, Yang JC, Xu WB (2011) Didymoplexis vietnamica, a newly recorded species of Didymoplexis (Orchidaceae) from China. Guihaia, 31, 578-580. (in Chinese with English abstract) [黄俞淞, 陆茂新, 杨金财, 许为斌 (2011) 中国双唇兰 属(兰科)一新记录种——中越双唇兰. 广西植物, 31, 578-580.]

Huang YS, Wu WH, Jiang RH, Liu SY, Liu Y, Li XK (2013) Primary study on species diversity of plant in Longgang National Nature Reserve of Guangxi. Guihaia, 33, 346-355. (in Chinese with English abstract) [黄俞㳂, 吴望辉, 蒋日红, 刘茙源, 刘 演, 李先琨 (2013) 广西弄岗国家级自然保护区植物物种多样性初步研究. 广西植物, 33, 346-355.]

Jesse LR, Yang J, Zhang GC, Cao M, Tang Y, Timothy KH (2014) The role of functional traits and individual variation in the co-occurrence of Ficus species. Ecology, 95, 978-990.

Jia HR, Chen Y, Yuan ZL, Ye YZ, Huang Q (2016) Effects of environmental and spatial heterogeneity on tree community assembly in Baotianman National Nature Reserve, Henan, China. Polish Journal of Ecology, 63, 175-183.

Jiang YL, Bai KD, Guo YL, Wang B, Li DX, Li XK, Liu ZS (2016) Floral traits of woody plants and their habitat differentiations in a northern tropical karst forest. Biodiversity Science, 24, 148-156. (in Chinese with English abstract) [蒋裕良, 白坤栋, 郭屹立, 王斌, 李冬兴, 李先琨, 刘志尚 (2016) 北热带喀斯特森林木本植物花性状及其生境分异. 生物多样性, 24, 148-156.] 
Jiang ZH, Jin GZ (2010) Effects of selection cutting on diameter growth and vertical growth among major tree species in the mixed broadleaved-Korean pine forest. Acta Ecologica Sinica, 30, 5843-5852. (in Chinese with English abstract) [蒋子涵, 金光泽 (2010) 择伐对阔叶红松林主要树种径向与纵向生长的影响. 生态学报, 30, 5843-5852.]

Jiang ZH, Jin GZ (2010) Effects of selective cutting on intra- and interspecies competitions among major tree species in mixed broadleaved-Korean pine forest. Chinese Journal of Applied Ecology, 21, 2179-2186. (in Chinese with English abstract) [蒋子 涵，金光泽 (2010) 择伐对阔叶红松林主要组成树种种内、种间竞争的影响. 应用生态学报, 21, 2179-2186.]

Jin GZ, Li R, Li ZH, Kim JH (2007) Spatial pattern of Acer tegmentosum in the mixed broadleaved-Korean pine forest of Xiaoxing'an Mountains, China. Journal of Korean Forest Society, 96, 730-736.

Jin GZ, Li ZH, Tang Y, Kim JH (2009) Spatial distribution pattern and association of crowns and saplings for major tree species in the mixed broadleaved-Korean pine forest of Xiaoxing'an Mountains, China. Journal of Korean Forest Society, 98, $189-196$.

Jin GZ, Liu L, Liu ZL, Kim JH (2010) Spatial pattern of Larix gmelini in a Spruce-fir valley forest of Xiaoxing'an Mountains, China. Journal of Korean Forest Society, 99, 720-725.

Jin GZ, Liu YY, Liu S, Kim JH (2007) Effect of gaps on species diversity in the naturally regenerated mixed broadleaved-Korean pine forest of the Xiaoxing'an Mountains, China. Journal of Ecology and Field Biology, 30, 325-330.

Jin GZ, Liu ZL, Cai HY, Tai BY, Jiang XL, Liu YY (2009) Coarse woody debris (CWD) in a spruce-fir valley forest in Xiaoxing'an Mountains, China. Journal of Natural Resources, 24, 1256-1266. (in Chinese with English abstract) [金光泽, 刘志理, 蔡慧颖, 台秉洋, 蒋小兰, 刘妍妍 (2009) 小兴安岭谷地云冷杉林粗木质残体的研究. 自然资源学报, 24, 1256-1266.]

Jin GZ, Tian YY, Zhao FX, Kim JH (2007) The pattern of natural regeneration by gap size in the broadleaved-Korean pine mixed forest of Xiaoxing'an mountains, China. Journal of Korean Forest Society, 96, 227-234.

Jin GZ, Xie XC, Tian YY, Kim JH (2006) The pattern of seed rain in the broadleaved-Korean pine mixed forest of Xiaoxing'an Mountains, China. Journal of Korean Forest Society, 95, 621-627.

Jin GZ, Yang GY, Ma JZ, Li LJ, Xu ZG, Zhao X, Hong MJ (2010) Effect of anthropogenic cone-picking on seed bank and seedling bank of Korean pine in the major forest types in Lesser Hing'an Mountains. Journal of Natural Resources, 25, 1845-1854. (in Chinese with English abstract) [金光泽, 杨桂燕, 马建章, 李兰君, 徐正刚, 赵雪, 洪美静 (2010) 松果采摘对小兴安岭主 要林型红松土壤种子库和幼苗库的影响. 自然资源学报, 25, 1845-1854.]

Jin GZ, Zhao FX, Liu L, Kim JH (2008) The production and spatial heterogeneity of litterfall in the mixed broadleaved-Korean pine forest of Xiaoxing'an Mountains, China. Journal of Korean Forest Society, 97, 165-170.

Jin Y, Chen JH, Mi XC, Ren HB, Ma KP, Yu MJ (2015) Impacts of the 2008 ice storm on structure and composition of an evergreen broad-leaved forest community in eastern China. Biodiversity Science, 23, 610-618. (in Chinese with English abstract) [金毅, 陈建华, 米湘成, 任海保, 马克平, 于明坚 (2015) 古田山 24 ha 森林动态监测样地常绿阔叶林群落结构和组成动态: 探 讨 2008 年冰雪灾害的影响. 生物多样性, 23, 610-618.]

Jin Y, Qian H, Yu MJ (2015) Phylogenetic structure of tree species across different life stages from seedlings to canopy trees in a subtropical evergreen broad-leaved forest. PLoS ONE, 10, e0131162.

Kang M, Chang SX, Yan ER, Wang XH (2014) Trait variability differs between leaf and wood tissues across ecological scales in subtropical forests. Journal of Vegetation Science, 25, 703-714.

Kuang X, Xing DL, Zhang ZC, Song HJ, Wang YY, Fang S, Yuan ZQ, Ye J, Lin F, Wang XG, Hao ZQ (2014) Species composition and community structure of a spruce-fir forest and a larch forest on the northern slope of Changbai Mountains, northeat China. Chinese Journal of Applied Ecology, 25, 2149-2157. (in Chinese with English abstract) [匡旭, 邢丁亮, 张昭臣,宋厚娟, 王芸 芸, 房帅, 原作强, 叶吉, 萄菲, 王绪高, 郝占庆 (2014) 长白山北坡云冷杉林和落叶松林物种组成与群落结构. 应用生 态学报, 25, 2149-2157.]

Lai JS, Coomes DA, Du XJ, Hsieh CF, Sun IF, Chao WC, Mi XC, Ren HB, Wang XG, Hao ZQ, Ma KP (2013) A general combined model to describe tree-diameter distributions within subtropical and temperate forest communities. Oikos, 122, $1636-1642$.

Lai JS, Mi XC, Ren HB, Ma KP (2009) Species-habitat associations change in a subtropical forest of China. Journal of Vegetation Science, 20, 415-423.

Lai JS, Mi XC, Ren HB, Ma KP (2010) Numerical classification of associations in subtropical evergreen broad-leaved forest based on multivariate regression trees-a case study of $24 \mathrm{hm}^{2}$ Gutianshan forest plot in China. Chinese Journal of Plant Ecology, 34, 761-769. (in Chinese with English abstract) [赖江山, 米湘成, 任海保, 马克平 (2010) 基于多元回归树的常绿阔叶林群丛 数量分类——古田山 24 公顷森林样地为例. 植物生态学报, 34, 761-769.]

Lai JS, Yang B, Lin DM, Kerkhoff AJ, Ma KP (2013) The allometry of coarse root biomass: log-transformed linear regression or nonlinear regression? PLoS ONE, 8, e77007.

Lan GY, Getzin S, Wiegand T, Hu YH, Xie GS, Zhu H, Cao M (2012) Spatial distribution and interspecific associations of tree species in a tropical seasonal rain forest of China. PLoS ONE, 7(9), e46074.

Lan GY, Hu YH, Cao M, Zhu H (2011) Topography related spatial distribution of dominant tree species in a tropical rain forest in China. Forest Ecology and Management, 262, 1507-1513.

Lan GY, Hu YH, Cao M, Zhu H, Wang H, Zhou SS, Deng XB, Cui JY, Huang JG, Liu LY, Xu HL, Song JP, He YC (2008) Establishment of Xishuangbanna tropical forest dynamics plot: species compositions and spatial distribution patterns. Journal of Plant Ecology (Chinese Version), 32, 287-298. (in Chinese with English abstract) [兰国玉, 胡跃华, 曹敏, 朱华, 王洪, 周仕 
顺, 邓晓保, 崔景云, 黄建国, 刘林云, 许海龙, 宋军平, 何有才 (2008) 西双版纳热带森林动态监测样地一一树种组成 与空间分布格局. 植物生态学报, 32, 287-298.]

Lan GY, Zhu H, Cao M (2012) Tree species diversity of a 20-ha plot in a tropical seasonal rainforest in Xishuangbanna, southwest China. Journal of Forest Research, 17, 432-439.

Lang AC, Härdtle W, Bruelheide H, Geibler C, Nadrowski K, Schuldt A, Yu MJ, Von Oheimb G (2010) Tree morphology responds to neighbourhood competition and slope in species-rich forests of subtropical China. Forest Ecology and Management, 260, $1708-1715$.

Legendre P, Mi XC, Ren HB, Ma KP, Yu MJ, Sun IF, He FL (2009) Partitioning beta diversity in a subtropical broad-leaved forest of China. Ecology, 90, 663-674.

Li BH, Hao ZQ, Bin Y, Zhang J, Wang M (2012) Seed rain dynamics reveals strong dispersal limitation, different reproductive strategies and response to climate in a temperate forest in Northeast China. Journal of Vegetation Science, 23, 271-279.

Li BH, Zhang J, Yao XL, Ye J, Wang XG, Hao ZQ (2008) Seasonal dynamics and spatial distribution patterns of herbs diversity in broadleaved Korean pine (Pinus koraiensis) mixed forest in Changbai Mountains. Chinese Journal of Applied Ecology, 19, 467-473. (in Chinese with English abstract) [李步杭，张健，姚晓琳，叶吉，王绪高，郝占庆 (2008) 长白山阔叶红松林草本 植物多样性季节动态及空间分布格局. 应用生态学报, 19, 467-473.]

Li C, Li FR, Wang SL, Yue SF, Wang XP, Liu YB, Jin GZ (2010) Stumpage coordinate extraction based on large-scale aerial photographs. Journal of Northeast Forestry University, 138, 31-34. (in Chinese with English abstract) [李超，李凤日，王胜蕾， 岳树峰, 王绪鹏, 刘银帮, 金光泽 (2010) 基于大比例尺航片的单株立木坐标提取. 东北林业大学学报, 138, 31-34.]

Li H, Wang XG, Liang C, Hao ZQ, Zhou LS, Ma S, Li XB, Yang S, Yao F, Jiang Y (2015) Aboveground-belowground biodiversity linkages differ in early and late successional temperate forests. Scientific Reports, 5, 122234.

Li JB, Zhu DG, Cui FX, Ni HW (2015) Analysis on the relationship between soil organic carbon content and soil organic carbon in different leaves of larch in alpine region. Territory \& Natural Resources Study, 5, 73-75. (in Chinese with English abstract) [李 金博, 朱道光, 崔福星, 倪红伟 (2015) 寒温带落叶松林不同林型土壤有机碳含量及相关性分析. 国土与自然资源研究, 5 , 73-75.]

Li L, Chen JH, Ren HB, Mi XC, Yu MJ, Yang B (2010) Spatial patterns of Castanopsis eyrei and Schima superba in mid-subtropical broadleaved evergreen forest in Gutianshan National Nature Reserve, China. Chinese Journal of Plant Ecology, 34, 241-252. (in Chinese with English abstract) [李立，陈建华，任海保，米湘成，于明坚，杨波 (2010) 古田山常绿阔叶林 优势树种甜槠和木荷的空间格局分析. 植物生态学报, 34, 241-252.]

Li L, Liu HF, Bai F, Zhu Y, Li GQ, Li WC, Sang WG (2011) Species composition and community structure of four deciduous broadleaved secondary forest in Dongling Mountain. Biodiversity Science, 19, 243-251. (in Chinese with English abstract) [李 亮, 刘海丰, 白帆, 祝燕, 李广起, 李文超, 桑卫国 (2011) 东灵山 4 种落叶阔叶次生林的物种组成与群落结构. 生物多样 性, 19, 243-251.]

Li L, Wei SG, Huang ZL, Ye WH, Cao HL (2008) Spatial patterns and interspecific associations of three canopy species at different life stages in a subtropical forest, China. Journal of Integrative Plant Biology, 50, 1140-1150.

Li L, Wei SG, Huang ZL, Ye WH, Cao HL, Wang ZG, Lian JY, Sun IF, Ma KP, He FL (2009) Spatial distributions of tree species in a subtropical forest of China. Oikos, 118, 495-502.

Li L, Ye WH, Wei SG, Lian JY, Huang ZL (2014) Spatial patterns and associations between species belonging to four genera of the Lauraceae family. PLoS ONE, 9, e111500.

Li N, Xu WB, Lai JS, Yang B, Lin DM, Ma KP (2013) The coarse root biomass of eight common tree species in subtropical evergreen forest. Chinese Science Bulletin, 58, 329-335. (in Chinese with English abstract) [李宁，徐武兵，赖江山，杨波，林 敦梅, 马克平 (2013) 亚热带常绿阔叶林 8 个常见树种粗根生物量. 科学通报, 58, 329-335.]

Li QX, Wang XG, Jiang MX, Wu Y, Yang XL, Liao C, Liu F (2016) How environmental and vegetation factors affect spatial patterns of soil carbon and nitrogen in a subtropical mixed forest in Central China. Journal of Soils and Sediments, DOI 10.1007/s11368-016-1491-5.

Li SQ, Wang GH, Shi ZP, Li XK, Xiao ZS, Zhou QH (2016) Infrared camera traps for monitoring mammal and bird diversity and activity pattern in limestone habitats. Acta Theriologica Sinica, 36, 272-281. (in Chinese with English abstract) [李生强, 汪国 海, 施泽攀, 李先琨, 肖治术, 周岐海 (2016) 红外相机技术监测喀斯特生兽类和鸟类多样性及活动节律. 兽类学报, 36, 272-281.]

Li XL, Wang H, Zheng Z, Lin LX, Deng XB, Cao M (2009) Composition, spatial distribution and survival during the dry season of tree seedlings in a tropical forest in Xishuangbanna, SW China. Chinese Journal of Plant Ecology, 33, 658-671. (in Chinese with English abstract) [李晓亮，王洪，郑征，林露湘，邓晓保，曹敏 (2009) 西双版纳热带森林树种幼苗的组成、空间分布和旱 季存活. 植物生态学报, 33, 658-671.]

Li XP, Chang SX, Liu JT, Zheng ZM, Wang XH (2017) Topography-soil relationships in a hilly evergreen broadleaf forest in subtropical China. Journal of Soils \& Sediments, 17, 1101-1115.

Lian JY, Chen C, Huang ZL, Cao HL, Ye WH (2015) Community composition and stand age in a subtropical forest, southern China. Biodiversity Science, 23, 174-182. (in Chinese with English abstract) [练琚愉，陈灿，黄忠良，曹洪麟，叶万辉 (2015) 鼎湖 山南亚热带常绿阔叶林不同成熟度群落特征的比较. 生物多样性, 23, 174-182.] 
Lin DM, Anderson-Teixeira KJ, Lai JS, Mi XC, Ren HB, Ma KP (2016) Traits of dominant tree species predict local scale variation in forest aboveground and topsoil carbon stocks. Plant and Soil, 409, 435-446.

Lin DM, Lai JS, Mi XC, Ren HB, Ma KP (2013) Spatial variation in community structure of a subtropical evergreen broad-leaved forest: implications for sampling design. Chinese Science Bulletin, 58, 1181-1186.

Lin DM, Lai JS, Mi XC, Ren HB, Ma KP (2013) Spatial variation in community structure of a subtropical evergreen broad-leaved forest: implications for sampling design. Chinese Science Bulletin, 58, 69-74. (in Chinese, English vision: , 58, 1181-1186.

Lin DM, Lai JS, Muller-Landau HC, Mi XC, Ma KP (2012) Topographic variation in aboveground biomass in a subtropical evergreen broad-leaved forest in China. PLoS ONE, 7, e48244.

Lin DM, Lai JS, Yang B, Song P, Li N, Ren HB, Ma KP (2015) Forest biomass recovery after different anthropogenic disturbances: relative importance of changes in stand structure and wood density. European Journal of Forest Research, 134, 769-780.

Lin F, Comita L, Wang XG, Bai XJ, Yuan ZQ, Xing DL, Hao ZQ (2014) The contribution of understory light availability and biotic neighborhood to seedling survival in secondary versus old-growth temperate forest. Plant Ecology, 215, 795-807.

Lin GJ, Huang ZL, Zhu L, Ouyang XJ (2010) Beta diversity of forest community on Dinghushan. Acta Ecologica Sinica, 30, 4875-4880. (in Chinese with English abstract) [林国俊, 黄忠良, 竺琳, 欧阳学军 (2010) 鼎湖山森林群落 $\beta$ 多样性. 生态学 报, 30, 4875-4880.]

Lin GJ, Stralberg D, Gong GQ, Huang ZL, Ye WH, Wu LF (2013) Separating the effects of environment and space on tree species distribution: from population to community. PLoS ONE, 8, e56171.

Lin LX, Comita L, Zheng Z, Cao M (2012) Seasonal differentiation in density-dependent seedling survival in a tropical rainforest. Journal of Ecology, 100, 905-914.

Lin YW, Jin GZ (2016) Effects of root resectioning on soil microbial biomass in six forest types in the Xiaoxing'an Mountains during freezing-thawing cycles. Acta Ecologica Sinica, 36, 6159-6169. (in Chinese with English abstract) [林尤伟, 金光泽 (2016) 冻融期去根处理对小兴安岭 6 种林型土壤微生物量的影响. 生态学报, 36, 6159-6169.]

Liu C, Liu YK, Jin GZ (2014) Seasonal dynamics of soil microbial biomass in six forest types in Xiaoxing'an Mountains, China. Acta Ecologica Sinica, 34, 451-459. (in Chinese with English abstract) [刘纯, 刘延坤, 金光泽 (2014) 小兴安岭 6 种森林类 型土壤微生物量的季节变化特征. 生态学报, 34, 451-459.]

Liu HB, Wang QG, Lu JM, Xu YZ, Lu ZJ, Qiao XJ, Bao DC, Guo YL, Meng HJ, Jiang MX (2014) Root-sprouting ability in an evergreen and deciduous broad-leaved mixed forest. Chinese Science Bulletin, 59, 3491-3498. (in Chinese with English abstract) [刘海波, 王庆刚, 路俊盟, 徐耀粘, 卢志军, 乔秀娟, 鲍大川, 郭屹立, 孟红杰, 江明喜 (2014) 八大公山常绿落叶阔叶 混交林根萌能力. 科学通报, 59, 3491-3498.]

Liu HF, Li L, Sang WG (2011) Species composition and community structure of the Donglingshan forest dynamic plot in a warm temperate deciduous broad-leaved secondary forest, China. Biodiversity Science, 19, 232-242. (in Chinese with English abstract) [刘海丰, 李亮, 桑卫国 (2011) 东灵山暖温带落叶阔叶次生林动态监测样地:物种组成与群落结构. 生物多样性, 19, 232-242.]

Liu HF, Sang WG, Xue DY (2013) Topographical habitat variability of dominant species populations in a warm temperate forest. Chinese Journal of Ecology, 32, 1-7. (in Chinese with English abstract) [刘海丰, 桑卫国, 薛达元 (2013) 暖温带森林优势种 群的地形生境变异性. 生态学杂志, 32, 1-7.]

Liu HF, Xue DY, Sang WG (2012) Effect of topographic factors on the relationship between species richness and aboveground biomass in a warm temperate forest. Ecology and Environmental Sciences, 21, 1403-1407. (in Chinese with English abstract) [刘海丰, 薛达元, 桑卫国 (2012) 地形因子对暖温带森林群落物种丰富度-地上生物量关系的影响. 生态环境学报, 21, 1403-1407.]

Liu HF, Xue DY, Sang WG (2014) Species diffusion and niche differentiation of the warm temperate deciduous broad-leaved forest in its functional development process. Chinese Science Bulletin, 59, 2359-2366. (in Chinese with English abstract) [刘海丰, 薛 达元, 桑卫国 (2014) 暖温带森林功能发育过程中的物种扩散和生态位分化. 科学通报, 59, 2359-2366.]

Liu HM, Shen GC, Ma ZP, Yang QS, Xia JY, Fang XF, Wang XH (2016) Conspecific leaf litter-mediated effect of conspecific adult neighborhood on early-stage seedling survival in a subtropical forest. Scientific Reports, 6, 37830.

Liu HM, Yang QS, Fang XF, Ma ZP, Shen GC, Zhang ZG, Wang ZH, Wang XH (2015) Influences on gap species richness in a subtropical evergreen broadleaved forest. Biodiversity Science, 23, 149-156. (in Chinese with English abstract) [刘何铭, 杨庆 松, 方晓峰, 马遵平, 沈国春, 张志国, 王樟华, 王希华 (2015) 亚热带常绿阔叶林林窗物种丰富度的影响因素. 生物多 样性, 23, 149-156.]

Liu JC, Chen JL, Jin GZ (2014) Response of soil organic carbon and nutrients to simulated nitrogen deposition in typical mixed broadleaved-Korean pine forest. Bulletin of Botanical Research, 34, 121-130. (in Chinese with English abstract) [刘建才, 陈金 玲, 金光泽 (2014) 模拟氮沉降对典型阔叶红松林土壤有机碳和养分的影响. 植物研究, 34, 121-130.]

Liu JJ, Tan YH, Ferry SJW (2014) Topography related habitat associations of tree species traits, composition and diversity in a Chinese tropical forest. Forest Ecology and Management, 330, 75-81.

Liu JY, Zheng Z (2012) Abundance and distribution pattern of tree cavity in tropical forest in Xishuangbanna, Southwest China. Chinese Journal of Ecology, 31, 271-275. (in Chinese with English abstract) [刘俊雁, 郑征 (2012) 西双版纳热带森林树洞丰 富度及其分配特点. 生态学杂志, 31, 271-275.] 
Liu L, Wang ZF, Li QM, Ye WH, Cao HL, Wang ZM (2013) Isolation and characterization of microsatellite markers in Beilschmiedia roxburghiana (Lauraceae). Applications in Plant Sciences, 1, 1200549.

Liu Q, Cai HY, Jin GZ (2013) Effects of selective cutting on the carbon density and net primary productivity of a mixed broadleaved-Korean pine forest in Northeast China. Chinese Journal of Applied Ecology, 24, 2709-2716. (in Chinese with English abstract) [刘琦, 蔡慧颖, 金光泽 (2013) 择伐对阔叶红松林碳密度和净初级生产力的影响. 应用生态学报, 24, 2709-2716.]

Liu S, Jin GZ (2008) Spatiotemporal dynamics of seed rain in a broadleaved-Korean pine mixed forest in Xiaoxing'an Mountains, China. Acta Ecologica Sinica, 28, 5731-5740. (in Chinese with English abstract) [刘双, 金光泽 (2008) 小兴安岭阔叶红松 (Pinus koraiensis)林种子雨的时空动态. 生态学报, 28, 5731-5740.]

Liu WP, Cao HL, Liu W, Lian JY, Wu LF (2011) Study on diversity of monsoon evergreen broad leaved forest in different kinds of habitat in Dinghushan. Journal of Anhui Agricultural Sciences, 39, 16159-16163. (in Chinese with English abstract) [刘文平, 曹洪麟, 刘卫, 练琚愉, 吴林芳 (2011) 鼎湖山季风常绿阔叶林不同生境物种多样性研究. 安徽农业科学, 39, 16159-16163.]

Liu XJ, Ma KP (2015) Plant functional traits—concepts, applications and future directions. Scientia Sinica Vitae, 45, 325-339. (in Chinese with English abstract) [刘晓娟, 马克平 (2015) 植物功能性状研究. 中国科学: 生命科学, 45, 325-339.]

Liu XJ, Ren SY, Li LX, Ye YZ, Yuan ZL, Wang T (2016) Detecting density dependence on tree survival in a deciduous broadleaved forest in Baotianman National Nature Reserve. Biodiversity Science, 26, 639-648. (in Chinese with English abstract) [刘晓静, 任思远，李鹿金，叶永忠，袁志良，王婷 (2016) 宝天曼国家级自然保护区落叶阔叶林密度制约效应对树木存活的影响. 生物多样性, 26, 639-648.]

Liu XJ, Swenson NG, Lin DM, Mi XC, Umana MN, Schmid B, Ma KP (2016) Linking individual-level functional traits to tree growth in a subtropical forest. Ecology, 97, 2396-2405.

Liu XJ, Swenson NG, Wright SJ, Zhang LW, Song K, Du YJ, Zhang JL, Mi XC, Ren HB, Ma KP (2012) Covariation in plant functional traits and soil fertility within two species-rich forests. PLoS ONE, 7, e34767.

Liu XJ, Swenson NG, Zhang JL, Ma KP (2013) The environment and space, not phylogeny, determine trait dispersion in a subtropical forest. Functional Ecology, 27, 264-272.

Liu YY, Jin GZ (2009) Influence of topography on coarse woody debris in a mixed broadleaved-Korean pine forest in Xiaoxing'an Mountains, China. Acta Ecologica Sinica, 29, 1398-1407. (in Chinese with English abstract) [刘妍妍, 金光泽 (2009) 地形对 小兴安岭阔叶红松(Pinus koraiensis)林粗木残质体分布的影响. 生态学报, 29, 1398-1407.]

Liu YY, Jin GZ (2010) Character of coarse woody debris in a mixed broad-leaved Korean pine forest in Xiaoxing'an Mountains, China. Scientia Silvae Sinicae, 46(4), 8-14. (in Chinese with English abstract) [刘妍妍，金光泽 (2010) 小兴安岭阔叶红松林 粗木质残体基础特征. 林业科学, 46(4), 8-14.]

Liu YY, Jin GZ (2010) Spatial point pattern analysis for coarse woody debris in a mixed broadleaved-Korean pine forest in Xiaoxing'an Mountains, China. Acta Ecologica Sinica, 30, 6072-6081. (in Chinese with English abstract) [刘妍妍, 金光泽 (2010) 小兴安岭阔叶红松林粗木质残体空间分布的点格局分析. 生态学报, 30, 6072-6081.]

Liu YY, Jin GZ, Li FR (2014) Influence of forest gaps on seedling establishment in a mixed broadleaved-Korean pine (Pinus koraiensis) forest in Xiao Hinggan Mountains. Chinese Science Bulletin, 59, 2396-2406. (in Chinese with English abstract) [刘 妍妍，金光泽，李凤日 (2014) 典型阔叶红松林林隙对幼苗建立的影响. 科学通报, 59, 2396-2406.]

Liu YY, Jin GZ, Li R (2010) Storage characteristics of coarse woody debris in a mixed broadleaved-Korean pine forest in Xiaoxing'an Mountains, China. World Forestry Research, 23(9), 24-30. (in Chinese with English abstract) [刘妍妍, 金光泽, 黎如 (2010) 小兴安岭阔叶红松林粗木质残体的咜量特征. 世界林业研究, 23(9), 24-30.]

Liu YY, Li FR, Jin GZ (2014) Spatial patterns and associations of four species in an old-growth temperate forest. Journal of Plant Interactions, 9, 745-753.

Liu ZL, Chen JM, Jin GZ, Qi YJ (2015) Estimating seasonal variations of leaf area index using litterfall collection and optical methods in four mixed evergreen-deciduous forests. Agricultural and Forest Meteorology, 209, 36-48.

Liu ZL, Jin GZ (2012) Estimation of leaf area index of three forest types in Xiaoxing'an Mountains of northeast China. Chinese Journal of Applied Ecology, 23, 2437-2444. (in Chinese with English abstract) [刘志理, 金光泽 (2012) 小兴安岭三种林型叶 面积指数的估测. 应用生态学报, 23, 2437-2444.]

Liu ZL, Jin GZ (2013) Estimation of leaf area index of secondary Betula platyphylla forest in Xiaoxing'an Mountains. Acta Ecologica Sinica, 33, 2505-2513. (in Chinese with English abstract) [刘志理, 金光泽 (2013) 小兴安岭白桦次生林叶面积指 数的估测. 生态学报, 33, 2505-2513.]

Liu ZL, Jin GZ (2014) Estimation of seasonal changes in leaf area index based on optical methods in spruce-fir valley forest. Chinese Journal of Applied Ecology, 25, 3420-3428. (in Chinese with English abstract) [刘志理，金光泽 (2014) 基于光学仪 器法测定谷地云冷杉林叶面积指数的季节变化. 应用生态学报, 25, 3420-3428.]

Liu ZL, Jin GZ (2015) Using litter collection and tree data to model leaf area index in the mixed broadleaved-Korean pine forest in the Xiaoxing'an Mountains, China. Acta Ecologica Sinica, 35, 3190-3198. (in Chinese with English abstract) [刘志理, 金光泽 (2015) 利用调落物法和林木因子模拟小兴安岭阔叶红松林叶面积指数. 生态学报, 35, 3190-3198.] 
Liu ZL, Jin GZ (2016) Bias analysis of seasonal changes of leaf area index derived from optical methods. Scientia Silvae Sinicae, 52(9), 11-21. (in Chinese with English abstract) [刘志理, 金光泽 (2016) 光学仪器法测定叶面积指数季节变化的误差分析. 林业科学, 52(9), 11-21.]

Liu ZL, Jin GZ, Chen JM, Qi YJ (2015) Evaluating optical measurements of leaf area index against litter collection in a mixed broadleaved-Korean pine forest in China. Trees: Structure and Function, 29, 59-73.

Liu ZL, Jin GZ, Qi YJ (2012) Estimate of leaf area index in an old-growth mixed broadleaved-Korean pine forest in northeastern China. PLoS ONE, 7, e32155.

Liu ZL, Jin GZ, Zhou M (2014) Measuring seasonal dynamics of leaf area index in a mixed conifer-broadleaved forest with direct and indirect methods. Chinese Journal of Plant Ecology, 38, 843-856. (in Chinese with English abstract) [刘志理, 金光泽, 周 明 (2014) 利用直接法和间接法测定针阔混交林叶面积指数的季节动态. 植物生态学报, 38, 843-856.]

Liu ZL, Jin GZ, Zhou M (2016) Evaluation and correction of optically derived leaf area index in different temperate forests. iForest: Biogeosciences and Forestry, 9, 55-62.

Liu ZL, Qi YJ, Jin GZ (2013) Seasonality and spatial pattern of leaf area index of a spruce-fir forest at the valley in Xiaoxing'an Mountains. Scientia Silvae Sinicae, 49(8), 58-64. (in Chinese with English abstract) [刘志理, 戚玉娇, 金光泽 (2013) 小兴安 岭谷地云冷杉林叶面积指数的季节动态及空间格局. 林业科学, 49(8), 58-64.]

Liu ZL, Wang CK, Chen JM, Wang XC, Jin GZ (2015) Empirical models for tracing seasonal changes in leaf area index in deciduous broadleaf forests by digital hemispherical photography. Forest Ecology and Management, 351, 66-77.

Liu ZL, Wang XC, Chen JM, Wang CK, Jin GZ (2015) On improving the accuracy of digital hemispherical photography measurements of seasonal leaf area index variation in deciduous broadleaf forests. Canadian Journal of Forest Research, 45, $721-731$.

Lu JM, Johnson DJ, Qiao XJ, Lu ZJ, Wang QG, Jiang MX (2015) Density dependence and habitat preference shape seedling survival in a subtropical forest in central China. Journal of Plant Ecology, 8, 568-577.

Lu P, Jin Y, Chen JH, Li MH, Yu MJ (2013) Influences of geographical distance and topographic difference on $\beta$ diversity of two large-scale forest dynamics plots. Biodiversity Science, 21, 554-563. (in Chinese with English abstract) [卢品, 金毅, 陈建华, 李铭红, 于明坚 (2013) 地理距离和地形差异对两个大型森林动态样地 $\beta$ 多样性的影响. 生物多样性, 21, 554-563.]

Lu ZJ, Bao DC, Guo YL, Lu JM, Wang QG, He D, Zhang KH, Xu YZ, Liu HB, Meng HJ, Huang HD, Wei XZ, Liao JX, Qiao XJ, Jiang MX, Gu ZR, Liao CL (2013) Community composition and structure of Badagongshan (BDGS) Forest Dynamics Plot in a mid-subtropical mountain evergreen and deciduous broad-leaved mixed forest, Central China. Plant Science Journal, 31, 336-344. (in Chinese with English abstract) [卢志军, 鲍大川, 郭屹立, 路俊盟, 王庆刚, 何东, 张奎汉, 徐耀粘, 刘海波, 孟红杰, 黄汉东, 魏新增, 廖建雄, 乔秀娟, 江明喜, 谷志容, 廖春林 (2013) 八大公山亚热带山地常绿落叶阔叶混交林 物种组成与结构. 植物科学学报, 31, 336-344.]

Lu ZJ, Liu FL, Wu H, Jiang M (2015) Species composition, size class, and spatial patterns of snags in the Badagongshan (BDGS) mixed evergreen and deciduous broad-leaved forest in central China. Biodiversity Science, 23, 167-173. (in Chinese with English abstract) [卢志军, 刘福玲, 吴浩, 江明喜 (2015) 八大公山常绿落叶阔叶混交林枯立木物种组成、大小级与分布 格局. 生物多样性, 23, 167-173.]

Luo ZR, Mi XC, Chen XR, Ye ZL, Ding BY (2012) Density dependence is not very prevalent in a heterogeneous subtropical forest. Oikos, 121, 1239-1250.

Luo ZR, Yu MJ, Chen DL, Wu YG, Ding BY (2012) Spatial associations of tree species in a subtropical evergreen broad-leaved forest. Journal of Plant Ecology, 5, 346-355.

Ma J, Wu LF, Xiao W, Ye WH, Cao HL, Shen H (2015) Habitat adaptation of two dominant tree species in a subtropical monsoon forest: leaf functional traits and hydraulic properties. Guihaia, 35, 261-268. (in Chinese with English abstract) [马金, 吴林芳, 韦霄, 叶万辉, 曹洪麟, 沈浩 (2015) 鼎湖山季风常绿阔叶林两种优势树种的生境适应研究: 叶片功能性状和水力结构特 征. 广西植物, 35, 261-268.]

Ma L, Chen C, Shen Y, Wu LF, Huang ZL, Cao HL (2014) Determinants of tree survival at local-scale in a subtropical forest. Ecological Research, 29, 69-80.

Ma L, Huang MC, Shen Y, Cao HL, Wu LF, Ye WH, Lin GJ, Wang ZM (2015) Species diversity and community structure in forest fragments of Guangzhou, south China. Journal of Tropical Forest Science, 27, 148-157.

Ma L, Lian JY, Lin GJ, Cao HL, Huang ZL, Guan DS (2016) Forest dynamics and its driving forces of sub-tropical forest in South China. Scientific Reports, 6, 22561.

Man XX, Mi XC, Ma KP (2011) Effects of an ice storm on community structure of an evergreen broadleaved forest in Gutianshan National Nature Reserve, Zhejiang Province. Biodiversity Science, 19, 197-205. (in Chinese with English abstract) [曼兴兴, 米 湘成, 马克平 (2011) 雪灾对古田山常绿阔叶林群落结构的影响. 生物多样性, 19, 197-205.]

Mao HR, Chen JL, Jin GZ (2016) Effects of nitrogen addition on litter decomposition and nutrient release in typical broadleaf-Korean pine mixed forest. Journal of Beijing Forestry University, 38(3), 21-31. (in Chinese with English abstract) [毛 宏荵, 陈金玲, 金光泽 (2016) 氮添加对典型阔叶红松林凋落叶分解及养分释放的影响. 北京林业大学学报, 38(3), 21-31.]

Mi XC, Bao L, Chen JH, Ma KP (2014) Point process models, the dimensions of biodiversity and the importance of small-scale 
biotic interactions. Journal of Plant Ecology, 7, 126-133.

Mi XC, Swenson NG, Jia Q, Rao MD, Feng G, Ren HB, Bebber DP, Ma KP (2016) Stochastic assembly in a subtropical forest chronosequence: evidence from contrasting changes of species, phylogenetic and functional dissimilarity over succession. Scientific Reports, 6, 32596.

Mi XC, Swenson NG, Valencia R, Kress J, Erickson DL, Pérez ÁJ, Ren HB, Su SH, Gunatilleke N, Gunatilleke S, Hao ZQ, Ye WH, Cao M, Suresh, Dattaraja HS, Sukumar R, Ma KP (2012) The contribution of rare species to community phylogenetic diversity across a global network of forest plots. The American Naturalist, 180, E17-E30.

Mo XX, Shi LL, Zhang YJ, Zhu H, Slik JWF (2013) Change in phylogenetic community structure during succession of traditionally managed tropical rainforest in Southwest China. PLoS ONE, 8, e71464.

Ning YJ, Chen SP, Qian HY, Ren HB, Bebber D, Chen JH (2013) Diurnal and seasonal patterns of soil respiration in subtropical evergreen broad-leaved forests with different degrees of human disturbance in Gutianshan, Zhejiang Province. Chinese Science Bulletin, 58, 3839-3848. (in Chinese with English abstract) [宁亚军, 陈世苹, 钱海源, 任海保, Bebber D, 陈建华 (2013) 浙 江古田山亚热带常绿阔叶林不同干扰强度下土壤呼吸的日动态与季节变化. 科学通报, 58, 3839-3848.]

Niu HY, Li XY, Ye WH, Wang ZF, Cao HL, Wang ZM (2012) Isolation and characterization of 36 polymorphic microsatellite markers in Schima superba (Theaceae). American Journal of Botany, e123-e126.

Niu HY, Wang ZF, Lian JY, Ye WH, Shen H (2011) New progress in community assembly: community phylogenetic structure combining evolution and ecology. Biodiversity Science, 19, 275-283. (in Chinese with English abstract) [牛红玉, 王峥峰, 练 琚愉, 叶万辉, 沈浩 (2011) 群落构建研究的新进展: 进化和生态相结合的群落谱系结构研究. 生物多样性, 19, 275-283.]

Niu HY, Ye WH, Wang ZF, Chen Y, Cao HL, Wu LF, Wang ZM (2013) Development and characterization of 16 new polymorphic microsatellite loci for Schima superba (Theaceae). Silvae Genetica, 62, 124-127.

Niu XM, Shi S, Wang ZF, Ye WH, Hao ZQ (2014) Spatial autocorrelation of genetic structure of Prunus padus population in broadleaved Korean pine forest of Changbai Mountains. Chinese Journal of Applied Ecology, 25, 305-310. (in Chinese with English abstract) [牛小敏, 师帅, 王峥峰, 叶万辉, 郝占庆 (2014) 长白山阔叶红松林稠李居群遗传结构的空间自相关分 析. 应用生态学报, 25, 305-310.]

Pan X, Zhou RF, Gu SS, Xia JT, Wang DD, Ding BY (2013) Structure and distribution pattern of Cyclobalanopsis multinervis population in an evergreen broad-leaved forest in Baishanzu. Subtripical Plant Science, 42, 227-232. (in Chinese with English abstract) [潘霞, 周荣飞, 顾莎莎, 夏家天, 王丹丹, 丁炳扬 (2013) 百山祖北坡常绿阔叶林多脉青冈种群结构和分布格局. 亚热带植物科学, 42, 227-232.]

Pei NC, Lian JY, Erickson DL, Swenson NG, Kress WJ, Ye WH, Ge XJ (2011) Exploring tree-habitat associations in a Chinese subtropical forest plot using a molecular phylogeny generated from DNA barcode Loci. PLoS ONE, 6, e21273.

Pei NC, Zhang JL, Mi XC, Ge XJ (2011) Plant DNA barcodes promote the development of phylogenetic community ecology. Biodiversity Science, 19, 284-294. (in Chinese with English abstract) [裴男才, 张金龙, 米湘成, 葛学军 (2011) 植物 DNA 条形码促进系统发育群落生态学发展. 生物多样性, 19, 284-294.]

Peng GQ, Guo YL, Wei SJ, Chen HL, He YL, Tang SQ (2016) Age structure and spatial pattern of Camellia flavida in Nonggang. Jounal of Guangxi Normal University (Natural Science Edition), 34(3), 138-143. (in Chinese with English abstract) [彭国清, 郭屹立，韦素娟，陈海玲，何运林，唐绍清 (2016) 弄岗淡黄金花茶种群年龄结构与空间分布格局. 广西师范大学学报 (自然科学版), 34(3), 138-143.]

Piao TF, Comita LS, Jin GZ, Kim JH (2013) Density dependence across multiple life stages in a temperate old-growth forest of northeast China. Oecologia, 172, 207-217.

Qi YJ, Jin GZ, Liu ZL (2013) Optical and litter collection methods for measuring leaf area index in an old-growth temperate forest in northeastern China. Journal of Forest Research, 18, 430-439.

Qi YJ, Li FR, Liu ZL, Jin GZ (2014) Impact of understorey on overstorey leaf area index estimation from optical remote sensing in five forest types in northeastern China. Agricultural and Forest Meteorology, 198/199, 72-80.

Qian H, Hao ZQ, Zhang J (2014) Phylogenetic structure and phylogenetic diversity of angiosperm assemblages in forests along an elevational gradient in Changbaishan, China. Journal of Plant Ecology, 7, 154-165.

Qiao XJ, Li QX, Jiang QH, Lu JM, Franklin S, Tang ZY, Wang QG, Zhang JX, Lu ZJ, Bao DC, Guo YL, Liu HB, Xu YZ, Jiang MX (2015) Beta diversity determinants in Badagongshan, a subtropical forest in central China. Scientific Reports, 5, 17043.

Rao MD, Feng G, Zhang JL, Mi XC, Chen JH (2013) Effects of environmental filtering and dispersal limitation on species and phylogenetic beta diversity in Gutianshan National Nature Reserve. Chinese Science Bulletin, 58, 1204-1212. (in Chinese with English abstract) [饶米德，冯刚，张金龙，米湘成，陈建华 (2013) 生境过滤和扩散限制作用对古田山森林物种和系统发 育 $\beta$ 多样性的影响. 科学通报, 58, 1204-1212.]

Ren HB, Condit R, Chen B, Mi XC, Cao M, Ye WH, Hao ZQ, Ma KP (2013) Geographical range and local abundance of tree species in China. PLoS ONE, 8, e76374.

Ren SY, Wang T, Zhu Y, Ye YZ, Yuan ZL, Li C, Pan N, Li LX (2014) Phylogenetic structure of individuals with different DBH sizes in a deciduous broad-leaved forest community in the temperate-subtropical ecological transition zone, China. Biodiversity Science, 22, 574-582. (in Chinese with English abstract) [任思远, 王婷, 祝燕, 叶永忠, 袁志良, 李联, 潘娜, 李鹿金金 (2014) 
暖温带-北亚热带过渡带落叶阔叶林群落不同径级系统发育结构的变化. 生物多样性, 22, 574-582.]

Shen GC, He FL, Waagepetersen R, Sun IF, Hao ZQ, Chen ZS, Yu MJ (2013) Quantifying effects of habitat heterogeneity and other clustering processes on spatial distributions of tree species. Ecology, 94, 2436-2443.

Shen GC, Wiegand T, Mi XC, He FL (2013) Quantifying spatial phylogenetic structures of fully stem-mapped plant communities. Methods in Ecology and Evolution, 4, 1132-1141.

Shen GC, Yu MJ, Hu XS, Mi XC, Ren HB, Sun IF, Ma KP (2009) Species-area relationships explained by the joint effects of dispersal limitation and habitat heterogeneity. Ecology, 90, 3033-3041.

Shen Y, Santiago LS, Ma L, Lin GJ, Lian JY, Cao HL, Ye WH (2013) Forest dynamics of a subtropical monsoon forest in Dinghushan, China: recruitment, mortality and the pace of community change. Journal of Tropical Ecology, 29, 131-145.

Shen Y, Santiago LS, Shen H, Ma L, Lian JY, Cao HL, Lu HP, Ye WH (2014) Determinants of change in subtropical tree diameter growth with ontogenetic stage. Oecologia, 175, 1315-1324.

Shen Y, Yu SX, Lian JY, Shen H, Cao HL, Lu HP, Ye WH (2016) Inferring community assembly processes from trait diversity across environmental gradients. Journal of Tropical Ecology, 32, 290-299.

Shen Y, Yu SX, Lian JY, Shen H, Cao HL, Lu HP, Ye WH (2016) Tree aboveground carbon storage correlates with environmental gradients and functional diversity in a tropical forest. Scientific Reports, 6, 25304.

Shi BK, Gao WF, Cai HY, Jin GZ (2016) Spatial variation of soil respiration is linked to the forest structure and soil parameters in an old-growth mixed broadleaved-Korean pine forest in northeastern China. Plant and Soil, 400, 263-274.

Shi BK, Gao WF, Jin GZ (2015) Effects on rhizospheric and heterotrophic respiration of conversion from primary forest to secondary forest and plantations in northeast China. European Journal of Soil Biology, 66, 11-18.

Shi BK, Jin G, Wang ZY (2012) Temporal and spatial variability in soil respiration in five temperate forests in Xiaoxing'an Mountains, China. Acta Ecologica Sinica, 32, 5416-5428. (in Chinese with English abstract) [史宝库, 金光泽, 汪兆洋 (2012) 小兴安岭 5 种林型土壤呼吸时空变异. 生态学报, 32, 5416-5428.]

Shi BK, Jin GZ (2016) Variability of soil respiration at different spatial scales in temperate forests. Biology and Fertility of Soils, 52, 561-571.

Shi LL, Mortimer PE, Slik JWF, Zou XM, Xu JC, Feng WT, Qiao L (2014) Variation in forest soil fungal diversity along a latitudinal gradient. Fungal Diversity, 64, 305-315.

Shi ZP, Zhou QH, Li XK, Xiao ZS (2014) Estimation of species richness of mammals and birds using camera traps in Nonggang Forest Dynamics Plot, South China. Biodiversity Science, 22, 826-829. (in Chinese with English abstract) [施泽攀，周岐海, 李 先琨，肖治术 (2014) 弄岗森林动态监测样地及周边鸟兽的红外相机初步监测. 生物多样性, 22, 826-829.]

Song HJ, Ye J, Lin F, Yuan ZQ, Hao ZQ, Wang XG (2014) Effects of sampling scales on spatial patterns of woody species in forests. Chinese Science Bulletin, 59, 2388-2395. (in Chinese with English abstract) [宋厚娟，叶吉，萄菲，原作强，郝占庆，王绪高 (2014) 取样面积对森林木本植物空间分布格局分析的影响. 科学通报, 59, 2388-2395.]

Song HJ, Ye J, Shi S, Zhang ZC, Kuang X, Xing DL, Yuan ZQ, Lin F, Cai CJ, Wang XG, Hao ZQ (2014) Woody plant species composition and community structure in residual fragments of broad-leaved Korean pine mixed forests in Changbai mountains area. Chinese Journal of Applied Ecology, 25, 1239-1249. (in Chinese with English abstract) [宋厚娟，叶吉，师帅，张昭臣， 匡旭, 邢丁亮, 原作强, 落菲, 蔡成军, 王绪高, 郝占庆 (2014) 长白山区阔叶红松林残留片段木本植物物种组成与群落 结构. 应用生态学报, 25, 1239-1249.]

Song K, Mi XC, Jia Q, Ren HB, Bebber D, Ma KP (2011) Variation in phylogenetic structure of forest communities along a human disturbance gradient in Gutianshan forest, China. Biodiversity Science, 19, 190-196. (in Chinese with English abstract) [宋凯, 米湘成, 贾琪, 任海保, Bebber D, 马克平 (2011) 不同程度人为干扰对古田山森林群落谱系结构的影响. 生物多样性, 19, 190-196.]

Song P, Ren HB, Jia Q, Guo JX, Zhang NL, Ma KP (2015) Effects of historical logging on soil microbial communities in a subtropical forest in southern China. Plant and Soil, 397, 115-126.

Song XY, Li JQ, Zhang WF, Tang Y, Sun Z, Cao M (2016) Variant responses of tree seedling to seasonal drought stress along an elevational transect in tropical montane forests. Scientific Reports, 6, 36438.

Song XY, Nakamura A, Sun ZH, Tang Y, Cao M (2016) Elevational distribution of adult trees and seedlings in a tropical montane transect, southwest China. Mountain Research and Development, 36, 342-354.

Sun SJ, Zhang HM (2013) Cache sites preferred by small rodents facilitate cache survival in a subtropical primary forest, central China. Wildlife Research, 40, 294-302.

Suo YY, Yuan ZQ, Lin F, Wang XG, Ye J, Bai E, Hao ZQ (2016) Local-scale determinants of elemental stoichiometry of soil in an old-growth temperate forest. Plant and Soil, 408, 401-414.

Tan ZH, Deng XB, Hughes A, Tang Y, Cao M, Zhang WF, Yang XF, Sha LQ, Song L, Zhao JF (2015) Partial net primary production of a mixed dipterocarp forest: spatial patterns and temporal dynamics. Journal of Geophysical Research, Biogeosciences, 120, 570-583.

Tang HX, Chen TB, Liu SY, Nong DP, Meng YJ, Lu MX (2011) The population dynamics of Francois Langur Trachypithecus francoisi in Nonggang Nature Reserve, Guangxi, China. Sichuan Journal of Zoology, 30(1), 136-140. (in Chinese with English abstract) [唐华兴，陈天波，刘晟源，农登攀，蒙渊君，陆茂新 (2011) 广西弄岗自然保护区黑叶猴的种群动态. 四川动物， 30(1), 136-140.] 
Tang Y, Roger KL, Cao M (2012) Lianas as structural parasites: a re-evaluation. Chinese Science Bulletin, 57, 307-312.

Tang Y, Yang XF, Cao M, Baskin CC, Baskin JM (2011) Buttress trees increase environmental heterogeneity and regulate seedling diversity in a tropical rainforest. Plant and Soil, 338, 301-309.

Tian K, Chen L, Mi XC, Ma KP, Chen JH (2013) The effect of habitat filtering on tree seedling distribution in a subtropical evergreen broadleaf forest in China. Chinese Science Bulletin, 58, 3561-3569. (in Chinese with English abstract) [田锴, 陈否, 米湘成，马克平，陈建华 (2013) 亚热带常绿阔叶林木本植物幼苗分布格局及其对生境过滤的响应. 科学通报，58, 3561-3569.]

Umaňa M, Zhang CC, Cao M, Lin LX, Swenson N (2015) Commonness, rarity, and intraspecific variation in traits and performance in tropical tree seedlings. Ecology Letters, 18, 1329-1337.

Wang B, Huang YS, Li XK, Xiang WS, Ding T, Huang FZ, Lu SH, Han WH, Wen SJ, He LJ (2014) Species composition and spatial distribution of a 15 ha northern tropical karst seasonal rain forest dynamics study plot in Nonggang, Guangxi, southern China. Biodiversity Science, 22, 141-156. (in Chinese with English abstract) [王斌, 黄俞淞, 李先琨, 向悟生, 丁涛, 黄甫昭, 陆树华, 韩文衡, 文淑均, 何兰军 (2014) 弄岗北热带喀斯特季节性雨林 15 ha 监测样地的树种组成与空间分布. 生物多 样性, 22, 141-156.]

Wang B, Xiang WS, Ding T, Huang FZ, Wen SJ, Li DX, Guo YL, Li XK (2014) Spatial distribution of standing dead trees abundance and its impact factors in the karst seasonal rain forest, Nonggang, southern China. Chinese Science Bulletin, 59, 3479-3490. (in Chinese with English abstract) [王斌, 向悟生, 丁涛, 黄甫昭, 文淑均, 李冬兴, 郭屹立, 李先琨 (2014) 弄 岗喀斯特季节性雨林枯立木多度的空间分布及影响因子. 科学通报, 59, 3479-3490.]

Wang BQ, Liu ZL, Qi YJ, Jin GZ (2014) Seasonal dynamics of leaf area index using different methods in the Korean pine plantation. Acta Ecologica Sinica, 34, 1956-1964. (in Chinese with English abstract) [王宝琦, 刘志理, 戚玉娇, 金光泽 (2014) 利用不同方法测定红松人工林叶面积指数的季节动态. 生态学报, 34, 1956-1964.]

Wang F, Wang ZF, Ye WH, Liang Y, Ma KP (2014) Isolation and characterization of microsatellite loci in an endemic species Styrax odoratissimus (Styracaceae) in subtropical forests. Conservation Genetics Resources, 6, 579-580.

Wang LW, Li BH, Ye J, Bai XJ, Yuan ZQ, Xing DL, Lin F, Shi S, Wang XG, Hao ZQ (2011) Dynamics of short-term tree mortality in broad-leaved Korean pine (Pinus koraiensis) mixed forest in the Changbai Mountains. Biodiversity Science, 19, 260-270. (in Chinese with English abstract) [王利伟, 李步杭, 叶吉, 白雪娇, 原作强, 邢丁亮, 萄菲, 师帅, 王绪高, 郝占庆 (2011) 长 白山阔叶红松林树木短期死亡动态. 生物多样性, 19, 260-270.]

Wang M, Shi S, Lin F, Hao ZQ, Jiang P, Dai GH (2012) Effects of soil water and nitrogen on growth and photosynthetic response of Manchurian ash (Fraxinus mandshurica) seedlings in northeastern China. PLoS ONE, 7, e30754.

Wang QG, Bao DC, Guo YL, Lu JM, Lu ZJ, Xu YZ, Zhang KH, Liu HB, Meng HJ, Jiang MX, Qiao XJ, Huang HD (2014) Species associations in a species-rich subtropical forest were not well-explained by stochastic geometry of biodiversity. PLoS ONE, 9 , e97300.

Wang QG, Ruwane PM, Lu ZJ, Scott F, Wang ZH, Li YQ, Chi XL, Bao DC, Guo YL, Lu JM, Xu YZ, Qiao XJ, Jiang MX (2016) Effects of topography on structuring species assemblages in a subtropical forest. Journal of Plant Ecology, DOI: 10.1093/jpe/rt47.

Wang QG, Xu YZ, Lu ZJ, Bao DC, Guo YL, Lu JM, Zhang KH, Liu HB, Meng HJ, Qiao XJ, Huang HD, Jiang MX (2014) Disentangling the effects of topography and space on the distributions of dominant species in a subtropical forest. Chinese Science Bulletin, 59, 5113-5122.

Wang T, Ren SY, Chen Y, Yuan ZL, Li LX, Pan N, Ye YZ (2014) Carbon storage dynamics of Pinus armandii forest at different diameter levels based on tree ring data in the Baotianman National Nature Reserve, central China. Chinese Science Bulletin, 59, 3499-3507. (in Chinese with English abstract) [王婷，任思远，陈云，袁志良，李鹿金金，潘娜，叶永忠 (2014) 基于树木年轮 信息的宝天曼不同径级华山松碳储量动态变化. 科学通报, 59, 3499-3507.]

Wang T, Ren SY, Yuan ZL, Zhu Y, Pan N, Li LX, Ye YZ (2014) Effects of density dependence on the spatial patterns of Quercus aliena var. acuteserrata trees in deciduous broad-leaved forest in the Baotianman Nature Reserve, central China. Biodiversity Science, 22, 449-457. (in Chinese with English abstract) [王婷, 任思远, 袁志良, 祝燕, 潘娜, 李鹿金金, 叶永忠 (2014) 密度 制约对宝天曼落叶阔叶林锐齿柇死亡前后分布格局的影响. 生物多样性, 22, 449-457.]

Wang W, Luo ZR, Zhou RF, Xu DM, Ai JG, Ding BY (2011) Habitat associations of woody plant species in Baishanzu subtropical broad-leaved evergreen forest. Biodiversity Science, 19, 134-142. (in Chinese with English abstract) [王伟, 骆争荣, 周荣飞, 许大明, 哀建国, 丁炳扬 (2011) 百山祖常绿润叶林木本植物的生境相关性分析. 生物多样性, 19, 134-142. ]

Wang W, Rao MD, Chen SW, Zhu DH, Mi XC, Zhang JT (2014) Effects of negative density dependence and habitat filtering on temporal variation in phylogenetic community structure of seedlings in a mid-subtropical forest. Chinese Science Bulletin, 59, 1844-1850. (in Chinese with English abstract) [王薇, 饶米德, 陈声文, 朱大海, 米湘成, 张金屯 (2014) 负密度制约和生境 过滤对古田山幼苗系统发育多样性时间变化的影响. 科学通报, 59, 1844-1850.]

Wang XG, Comita LS, Hao ZQ, Davies SJ, Ye J, Lin F, Yuan ZQ (2012) Local-scale drivers of tree survival in a temperate forest. PLoS ONE, 7, e29469.

Wang XG, Hao ZQ, Ye J, Zhang J, Li BH, Yao XL (2008) Relationships between species abundance and spatial distribution pattern of broad-leaved Korean pine (Pinus koraiensis) mixed forest in Changbai Mountains of China. Chinese Journal of Ecology, 27, 
145-150. (in Chinese with English abstract) [王绪高, 郝占庆, 叶吉, 张健, 李步杭, 姚晓琳 (2008) 长白山阔叶红松林物种 多度和空间分布格局的关系. 生态学杂志, 27, 145-150.]

Wang XG, Hao ZQ, Ye J, Zhang J, Li BH, Yao XL (2008) Spatial pattern of diversity in an old-growth temperate forest in Northeastern China. Acta Oecologica, 33, 345-354.

Wang XG, Hao ZQ, Ye J, Zhang J, Li BH, Yao XL (2008) Spatial variation of species diversity across scales in an old-growth temperate forest of China. Ecological Research, 23, 709-717.

Wang XG, Hao ZQ, Zhang J, Lian JY, Li BH, Yao XL (2009) Tree size distributions in an old-growth temperate forest. Oikos, 118, 25-36.

Wang XG, Li H, Bezemer TM, Hao ZQ (2016) Drivers of bacterial beta diversity in two temperate forests. Ecological Research, 31, $57-64$.

Wang XG, Swenson NG, Wiegand T, Wolf A, Howe R, Lin F, Ye J, Yuan ZQ, Shi S, Bai XJ, Xing DL, Hao ZQ (2013) Phylogenetic and functional diversity area relationships in two temperate forests. Ecography, 36, 883-893.

Wang XG, Wiegand T, Hao ZQ, Li BH, Ye J, Lin F (2010) Species associations in an old-growth temperate forest in north-eastern China. Journal of Ecology, 98, 674-686.

Wang XG, Wiegand T, Kraft NJB, Swenson NG, Davies SJ, Hao ZQ, Howe RW, Lin YJ, Ma KP, Mi XC (2016) Stochastic dilution effects weaken deterministic effects of niche-based processes in species rich forests. Ecology, 97, 347-360.

Wang XG, Wiegand T, Wolf A, Howe R, Davies SJ, Hao ZQ (2011) Spatial patterns of tree species richness in two temperate forests. Journal of Ecology, 99, 1382-1393.

Wang XG, Wiegand TT, Swenson N, Wolf A, Howe R, Hao ZQ, Lin F, Ye J, Yuan ZQ (2015) Mechanisms underlying local functional and phylogentic beta diversity in two temperate forests. Ecology, 96, 1062-1073.

Wang XG, Ye J, Li BH, Zhang J, Lin F, Hao ZQ (2010) Spatial distributions of species in an old-growth temperate forest, northeastern China. Canadian Journal of Forest Research, 40, 1011-1019.

Wang YH, Mi XC, Chen SW, Li MH, Yu MJ (2011) Regeneration dynamics of major tree species during 2002-2007 in a subtropical evergreen broad-leaved forest in Gutianshan National Nature Reserve in East China. Biodiversity Science, 19, 178-189. (in Chinese with English abstract) [汪殷华, 米湘成, 陈声文, 李铭红, 于明坚 (2011) 古田山常绿阔叶林主要树 种 2002-2007 年间更新动态. 生物多样性, 19, 178-189.]

Wang YY, Shi S, Lin F, Yuan ZQ, Ye J, Wang XG, Hao ZQ (2014) Reproductive traits and their correlation among woody plants in a broadleaf-Korean pine (Pinus koraiensis) mixed forest in northeast China. Chinese Science Bulletin, 59, 2407-2415. (in Chinese with English abstract) [王芸芸, 师帅, 萄菲, 原作强, 叶吉, 王绪高, 郝占庆 (2014) 长白山阔叶红松林木本植物 繁殖特征及其关联性. 科学通报, 59, 2407-2415.]

Wang ZF, Lian JY, Huang GM, Ye WH, Cao HL, Wang ZM (2012) Genetic groups in the common plant species Castanopsis chinensis and their associations with topographic habitats. Oikos, 121, 2044-2051.

Wang ZF, Lian JY, Ye WH, Cao HL, Wang ZM (2014) The spatial genetic pattern of Castanopsis chinensis in a large forest plot with complex topography. Forest Ecology and Management, 318, 318-325.

Wang ZF, Lian JY, Ye WH, Cao HL, Zhang QM, Wang ZM (2016) Pollen and seed flow under different predominant winds in wind-pollinated and wind-dispersed species Engelhardia roxburghiana. Tree Genetics \& Genomes, 12, 19.

Wang ZG, Ye WH, Cao HL, Huang ZL, Lian JY, Li L, Wei SG, Sun IF (2009) Species-topography association in a species-rich subtropical forest of China. Basic and Applied Ecology, 10, 648-655.

Wang ZG, Ye WH, Cao HL, Lian JY (2008) Spatial distribution of species diversity indices in a monsoon evergreen broadleaved forest at Dinghushan Mountain. Biodiversity Science, 16, 454-461. (in Chinese with English abstract) [王志高, 叶万辉, 曹洪 麟, 练琚愉 (2008) 鼎湖山季风常绿阔叶林物种多样性指数空间分布特征. 生物多样性, 16, 454-461.]

Warren-Thomas E, Zhou Y, Dong LJ, Yao XN, Yang MJ, Zhang XL, Qin Y, Liu YH, Sang WG, Axmacher JC (2014) Ground beetle assemblages in Beijing's new mountain forests. Forest Ecology and Management, 334, 369-376.

Wei SG, Li L, Chen ZC, Lian JY, Lin GJ, Huang ZL, Yin ZY (2014) Which models are appropriate for six subtropical forests: species-area and species-abundance models. PLoS ONE, 9, e95890.

Wei SG, Li L, Huang ZL, Ye WH, Gong GQ, Zhou XY, Lian JY (2013) Multifractal analysis of diversity scaling laws in a subtropical forest. Ecological Complexity, 13, 1-7.

Wei SG, Li L, Liu HG, Du YJ, Huang ZL (2008) Analyses of the dynamic state of Erythrophleum fordii population. Ecology and Environment, 17, 285-289. (in Chinese with English abstract) [魏识广, 李林, 刘海岗, 杜彦君, 黄忠良 (2008) 鼎湖山格木 种群动态分析. 生态环境, 17, 285-289.]

Wei SG, Li L, Walther B, Ye WH, Huang ZL, Cao HL, Lian JY, Wang ZG, Chen YY (2010) Comparative performance of species-richness estimators using data from a subtropical forest tree community. Ecological Research, 25, 93-101.

Wiegand T, Huth A, Getzin S, Wang XG, Hao ZQ, Gunatilleke CVS, Gunatilleke IAUN (2012) Testing the independent species' arrangement assertion made by theories of stochastic geometry of biodiversity. Proceedings of Royal Society B: Biological Sciences, 27, 3312-3320.

Wu JJ, Swenson NG, Brown C, Zhang CC, Yang J, Ci XQ, Li J, Sha LQ, Cao M, Lin LX (2016) How does habitat filtering affect the detection of conspecific and phylogenetic density dependence? Ecology, 97, 1182-1193.

Wu Q, Ding J, Yan H, Zhang SR, Fang T, Ma KP (2011) Effects of simulated precipitation and nitrogen addition on seedling growth 
and biomass in five tree species in Gutian Mountain, Zhejiang Province, China. Chinese Journal of Plant Ecology, 35, $256-267$. (in Chinese with English abstract) [吴茜，丁佳，闻慧，张守仁，方腾，马克平 (2011) 模拟降水变化和土壤施氮对浙江古田 山 5 个树种幼苗生长和生物量的影响. 植物生态学报, 35, 256-267.]

Xia SW, Chen J, Schaefer D, Detto M (2015) Scale-dependent soil macronutrient heterogeneity reveals effects of litterfall in a tropical rainforest. Plant and Soil, 391, 51-61.

Xia SW, Chen J, Schaefer D, Goodale UM (2016) Effect of topography and litterfall input on fine-scale patch consistency of soil chemical properties in a tropical rainforest. Plant and Soil, 404, 385-398.

Xiang WS, Ding T, Lü SH, Li XK (2015) A comparison of tree species diversity in two subtropical forests, Guangxi, southwest China. Journal of Resources and Ecology, 6, 208-216. (in English with Chinese Abstract)

Xiang WS, Lu SH, Wen SJ, Ding T, Wang B, Zhou AP, Huang FZ, Li XK (2015) Sample effects on species-area relationships of typical forests in karst and non-karst mixing distribution areas. Guihaia, 35, 309-316. (in Chinese with English abstract) [向悟生, 陆树华，文淑均，丁涛，王斌，周爱萍，黄甫昭，李先琨 (2015) 取样方式对喀斯特和非喀斯特混合分布区森林种一面积 关系的影响. 广西植物, 35, 309-316.]

Xiang WS, Nong CG, Wang B, Liu SY, Ding T, He LJ, Li XK, Huang FZ (2013) Growth models of Excentrodendron hsienmu population in a karst seasonal rainforest. Guihaia, 33, 285-290. (in Chinese with English abstract) [向悟生, 农重刚, 王斌, 刘 晟源, 丁涛, 何兰军, 李先琨, 黄甫昭 (2013) 喀斯特季节性雨林蚬木种群的增长模型. 广西植物, 33, 285-290.]

Xiang WS, Wang B, Ding T, Huang YS, Nong CG, Liu SY, Li XK (2013) Age structure and quantitative dynamics of Excentrodendron hsienmu population in a karst seasonal rain forest in South China. Chinese Journal of Ecology, 2, 825-831. (in Chinese with English abstract) [向悟生, 王斌, 丁涛, 农重刚, 李先琨, 刘晟源, 黄俞淞 (2013) 喀斯特季节性雨林蚬木种 群结构和数量动态. 生态学杂志, 2, 825-831.]

Xiao L, Yang QS, Liu HM, Xing JZ, Wang XH (2015) Character of seed rain of species with different dispersal modes in Tiantong evergreen broad leaved forest, Zhejiang Province. Journal of East China Normal University (Natural Science) , 122-132. (in Chinese with English abstract) [雷霄, 杨庆松, 刘何铭, 邢九州, 王希华 (2015) 浙江天童常绿阔叶林不同传播方式物种种 子雨的基本特征. 华东师范大学学报(自然科学版), 122-132.]

Xie WH, Yang XF, Li JN, Tao SL, Xiao ZS (2014) A preliminary study of the biodiversity of ground-dwelling small mammals in Badagongshan National Nature Reserve, Hunan Province. Biodiversity Science, 22, 216-222. (in Chinese with English abstract) [谢文华, 杨锡福, 李俊年, 陶双伦, 肖治术 (2014) 八大公山自然保护区地栖性小兽多样性初步研究. 生物多样性, 22, 216-222.]

Xie WH, Yang XF, Yu JJ, Li JN, Tao SL, Lu ZJ, Wang XZ, Xiao ZH (2014) A survey of mammals and birds using camera traps in Badagongshan Forest Dynamics Plot, Central China. Biodiversity Science, 22, 816-818. (in Chinese with English abstract) [谢 文华, 杨锡福, 于家捷, 李俊年, 陶双伦, 卢志军, 王学志, 肖治术 (2014) 运用红外相机对八大公山森林动态样地鸟兽 的初步调查. 生物多样性, 22, 816-818.]

Xie Y, Ma ZP, Yang QS, Fang XF, Zhang ZG, Yan ER, Wang XH (2012) Coexistence mechanisms of evergreen and deciduous trees based on topographic factors in Tiantong region, Zhejiang Province, eastern China. Biodiversity Science, 20, 159-167. (in Chinese with English abstract) [谢玉涁，马遵平，杨庆松，方晓峰，张志国，阎恩荣，王希华 (2012) 基于地形因子的天童 地区常绿树种和落叶树种共存机制研究. 生物多样性, 20, 159-167.]

Xing DL, Hao ZQ (2011) The principle of maximum entropy and its applications in ecology. Biodiversity Science, 19, 295-302. (in Chinese with English abstract) [邢丁亮, 郝占庆 (2011) 最大熵原理及其在生态学研究中的应用. 生物多样性, 19, 295-302.]

Xing DL, Swenson NG, Weiser MD, Hao ZQ (2014) Determinants of species abundance for eastern north American trees. Global Ecology and Biogeography, 23, 903-911.

Xing P, Zhang QB, Baker PJ (2012) Age and radial growth pattern of four tree species in a subtropical forest of China. Trees, 26, 283-290.

Xu LN, Jin GZ (2012) Species composition and community structure of a typical mixed broadleaved-Korean pine (Pinus koraiensis) forest plot in Liangshui Nature Reserve, northeast China. Biodiversity Science, 20, 470-481. (in Chinese with English abstract) [徐丽娜, 金光泽 (2012) 小兴安岭凉水典型阔叶红松林动态监测样地: 物种组成与群落结构. 生物多样性, 20, 470-481.]

$\mathrm{Xu}$ WB, Chen GK, Liu CR, Ma KP (2015) Latitudinal differences in species abundance distributions, rather than spatial aggregation, explain beta-diversity along latitudinal gradients. Global Ecology and Biogeography, 24, 1170-1180.

Xu WM, Ci XQ, Song CY, He TH, Zhang WF, Li QM, Li J (2016) Soil phosphorus heterogeneity promotes tree species diversity and phylogenetic clustering in a tropical seasonal rainforest. Ecology and Evolution, 6(24), 8719-8726.

Xu WM, Liu L, He TH, Cao M, Sha LQ, Hu YH, Li QM, Li J (2016) Soil properties drive a negative correlation between species diversity and genetic diversity in a tropical seasonal rainforest. Scientific Reports, 6, 20652.

Xu YJ, Lin DM, Mi XC, Ren HB, Ma KP (2014) Recovery dynamics of secondary forests with different disturbance intensity in the Gutianshan National Nature Reserve. Biodiversity Science, 22, 358-365. (in Chinese with English abstract) [徐远杰, 林敦梅, 米湘成, 任海保, 马克平 (2014) 古田山不同干扰程度森林的群落恢复动态. 生物多样性, 22, 358-365.]

Xu YZ, Franklin SB, Wang QG, Shi Z, Luo YQ, Lu ZJ, Zhang JX, Qiao XJ, Jiang MX (2015a) Topographic and biotic factors 
determine forest biomass spatial distribution in a subtropical mountain moist forest. Forest Ecology and Management, 357, 95-103.

Xu YZ, Zhang JX, Franklin SB, Liang JY, Ding P, Luo YQ, Lu ZJ, Bao DC, Jiang MX (2015b) Improving allometry models to estimate the above- and belowground biomass of subtropical forest, China. Ecosphere, 6, 289.

Yan ER, Wang XH, Chang SX, He FL (2013) Scaling relationships among twig size, leaf size and leafing intensity in a successional series of subtropical forests. Tree Physiology, 33, 609-617.

Yan ER, Yang XD, Chang SX, Wang XH (2013) Plant trait-species abundance relationships vary with environmental properties in subtropical forests in eastern China. PLoS ONE, 8, e61113.

Yan H, Wu Q, Ding J, Zhang SR (2012) Effects of precipitation and nitrogen addition on photosynthetically eco-physiological characteristics and biomass of four tree seedlings in Gutian Mountian, Zhejiang Province, China. Acta Ecologica Sinica, 33, 4226-4236. (in Chinese with English abstract) [阍慧，吴茜，丁佳，张守仁 (2012) 不同降水及氮添加对浙江古田山 4 种树 木幼苗光合生理生态特征与生物量的影响. 生态学报, 33, 4226-4236.]

Yan MY, Du XJ, Zhao AH, Peng MC (2015) Individual woody species-area relationship in a deciduous broad-leaved forest in Baotianman, Henan Province. Biodiversity Science, 23, 630-640. (in Chinese with English abstract) [间满玉，杜晓军，赵爱花， 彭明春 (2015) 河南宝天曼落叶阔叶林木本植物单物种-面积关系. 生物多样性, 23, 630-640.]

Yang J, Ci XQ, Lu MM, Zhang GC, Cao M, Li J, Lin LX (2014) Functional traits of tree species with phylogenetic signal co-vary with environmental niches in two large forest dynamics plots. Journal of Plant Ecology, 7, 115-125.

Yang J, Swenson NG, Cao M, Chuyong GB, Ewango CEN, Howe R, Kenfack D, Thomas DC, Wolf A, Lin LX (2013) A phylogenetic perspective on the individual species-area relationship in temperate and tropical tree communities. PLoS ONE, 8, e63192.

Yang J, Swenson NG, Zhang GC, Ci XQ, Cao M, Sha LQ, Li J, Ferry S, Lin LX (2015) Functional and phylogenetic beta diversity in a tropical tree assemblage. Scientific Reports, 5, 12731.

Yang J, Zhang GC, Ci XQ, Swenson NG, Cao M, Sha LQ, Li J, Baskin CC, Ferry SJW, Lin LX (2014) Functional and phylogenetic assembly in a Chinese tropical tree community across size classes, spatial scales and habitats. Functional Ecology, 28, 520-529.

Yang QS, Ma ZP, Xie YB, Zhang ZG, Wang ZH, Liu HM, Li P, Zhang N, Wang DL, Yang HB, Fang XF, Yan ER, Wang XH (2011) Community structure and species composition of an evergreen broadleaved forest in Tiantong's 20 ha dynamic plot, Zhejiang Province, eastern China. Biodiversity Science, 19, 215-223. (in Chinese with English abstract) [杨庆松，马遵平，谢玉涁，张 志国，王樟华，刘何铭，李萍，张娜，王达力，杨海波，方晓峰，阎恩荣，王希华 (2011) 浙江天童 20 ha 常绿阔叶林动态 监测样地的群落特征. 生物多样性, 19, 215-223.]

Yang QS, Shen GC, Liu HM, Wang ZH, Ma ZP, Fang XF, Zhang J, Wang XH (2016) Detangling the effects of environmental filtering and dispersal limitation on aggregated distributions of tree and shrub species: life stage matters. PLoS ONE, 11, e0156326.

Yang XD, Yan ER, Chang SX, Wang XH, Zhao YT, Shi QR (2014) Twig-leaf size relationships vary with soil moisture gradient in subtropical forests. Acta Oecologica, 60, 17-25.

Yang XD, Yan ER, Zhang ZH, Sun BW, Huang HX, Ali A, Ma WJ, Shi QR (2013) Tree architecture of overlapping species among successional stages in evergreen broad-leaved forests in Tiantong region, Zhejiang Province, China. Chinese Journal of Plant Ecology, 37, 611-619. (in Chinese with English abstract) [杨晓东，阎恩荣，张志浩，孙宝伟，黄海侠, Ali A，马文济，史青茹 (2013) 浙江天童常绿阔叶林演替阶段共有种的几何构型. 植物生态学报, 37, 611-619.]

Yang XF, Tang Y, Cao M (2010) Diaspore traits of 145 tree species from a tropical seasonal rain forest in Xishuangbanna, SW China. Acta Botanica Yunnanica, 32, 367-377. (in Chinese with English abstract) [杨小飞, 唐勇, 曹敏 (2010) 西双版纳热带 季节雨林 145 个树种繁殖体特征. 云南植物研究, 32, 367-377.]

Yao B, Yu JP, Liu XJ Mi XC, Ma KP (2015) Effect of seed traits on spatial aggregation of trees in a subtropical evergreen broad-leaved forest. Biodiversity Science, 23, 157-166. (in Chinese with English abstract) [姚蓓, 余建平, 刘晓娟, 米湘成, 马克平 (2015) 亚热带常绿阔叶林种子性状对木本植物聚集格局的影响. 生物多样性, 23, 157-166.]

Yao XL, Piao ZJ, Li BH, Zhang J, Wang XG, Ye J, Hao ZQ (2008) Pinus koraiensis seed consumption by rodents and birds. Chinese Journal of Applied Ecology, 19, 1759-1763. (in Chinese with English abstract) [姚晓琳, 朴正吉, 李步杭, 张健, 王绪 高, 叶吉, 郝占庆 (2008) 啮齿动物和鸟类对红松种子的消耗. 应用生态学报, 19, 1759-1763.]

Ye J, Hao ZQ, Wang XG, Bai XJ, Xing DL, Yuan ZQ (2014) Local-scale drivers of multi-stemmed tree formation in Acer, in a temperate forest of Northeast China. Chinese Science Bulletin, 59, 320-325.

Ye WH, Cao HL, Huang ZL, Lian JY, Wang ZG, Li L, Wei SG, Wang ZM (2008) Community structure of a $20 \mathrm{hm}^{2}$ lower subtropical evergreen broad-leaved forest plot in Dinghushan, China. Journal of Plant Ecology (Chinese Version), 32, $274-286$. (in Chinese with English abstract) [叶万辉, 曹洪麟, 黄忠良, 练琚愉, 王志高, 李林, 魏识广, 王章明 (2008) 鼎湖山南亚 热带常绿阔叶林 20 公顷样地群落特征研究. 植物生态学报, 32, 274-286.]

Yu XD, Luo TH, Zhou HZ (2014) Composition and distribution of ground-dwelling beetles among oak fragments and surrounding pine plantations in a temperate forest of North China. Insect Science, 21, 114-124.

Yuan ZL, Chen Y, Wei BL, Zhang BQ, Wang DY, Ye YZ (2013) Species habitat correlation analysis in temperate subtropical ecological transition zone. Acta Ecologica Sinica, 33, 7819-7826. (in Chinese with English abstract) [袁志良，陈云，韦博良， 
张斌强, 汪东亚, 叶永忠 (2013) 暖温带-北亚热带生态过渡区物种生境相关性分析. 生态学报, 33, 7819-7826.]

Yuan ZL, Wang T, Zhu XL, Sha YY, Ye YZ (2011) Patterns of spatial distribution of Quercus variabilis in deciduous broadleaf forests in Baotianman Nature Reserve. Biodiversity Science, 19, 224-231. (in Chinese with English abstract) [袁志良，王婷，朱 学灵, 沙迎迎, 叶永忠 (2011) 宝天曼落叶阔叶林样地栓皮栋种群空间格局. 生物多样性, 19, 224-231.]

Yuan ZQ, Gazol A, Lin F, Wang XG, Ye J, Suo YY, Fang S, Mellard J, Hao ZQ (2016) Scale-dependent effect of biotic interactions and environmental conditions in community assembly: insight from a large temperate forest plot. Plant Ecology, 217, 1003-1014.

Yuan ZQ, Gazol A, Lin F, Ye J, Shi S, Wang XG, Wang M, Hao ZQ (2013) Soil organic carbon in an old-growth temperate forest: spatial pattern, determinants and bias in its quantification. Geoderma, 195, 48-55.

Yuan ZQ, Gazol A, Wang XG, Lin F, Ye J, Zhang ZC, Suo YY, Kuang X, Wang YY, Jia SH, Hao ZQ (2016) Pattern and dynamics of biomass stock in old growth forests: the role of habitat and tree size. Acta Oecologica, 75, 15-23.

Yuan ZQ, Gazol A, Wang XG, Xing DL, Lin F, Bai XJ, Zhao YQ, Li BH, Hao ZQ (2012) What happens below the canopy? Direct and indirect influences of the dominant species on forest vertical layers. Oikos, 121, 1145-1153.

Yuan ZQ, Li BH, Bai XJ, Lin F, Shi S, Ye J, Wang XG, Hao ZQ (2010) Composition and seasonal dynamics of litter falls in a broad leaved Korean pine (Pinus koraiensis) mixed forest in Changbai Mountains, Northeast China. Chinese Journal of Applied Ecology, 21, 2171-2178. (in Chinese with English abstract) [原作强, 李步杭, 白雪娇, 落菲, 师帅, 叶吉, 王绪高, 郝占庆 (2010) 长白山阔叶红松林调落物组成及其季节动态. 应用生态学报, 21, 2171-2178.]

Yuan ZQ, Wang SP, Gazol A, Mellard J, Lin F, Ye J, Hao ZQ, Wang XG, Loreau M (2016) Multiple metrics of diversity have different effects on termperate forest functioning over succession. Oecologia, 182, 1175-1185.

Yuan ZQ, Wang XG, Gazol A, Li BH, Lin F, Ye J, Bai XJ, Hao ZQ (2011) Scale specific determinants of tree diversity in an old growth temperate forest in China. Basic and Applied Ecology, 12, 488-495.

Zhang B, Jin GZ (2014) Effects of selective cutting on the spatial and temporal distribution of fine biomass in mixed broadleaved Korean pine forest. Forest Research, 27, 240-245. (in Chinese with English abstract) [张生, 金光泽 (2014) 择伐对阔叶红松 林细根生物量及其时空分布的影响. 林业科学研究, 27, 240-245.]

Zhang DD, Luo P, Chen Y, Wang ZF, Ye WH, Cao HL (2014) Isolation and characterization of 12 polymorphic microsatellite markers in Engelhardia roxburghiana (Juglandaceae). Silvae Genetica, 63, 109-112.

Zhang J, Hao ZQ, Li BH, Ye J, Wang XG, Yao XL (2008) Composition and seasonal dynamics of seed rain in broad-leaved Korean pine (Pinus koraiensis) mixed forest, Changbai Mountain. Acta Ecologica Sinica, 28, 2445-2454. (in Chinese with English abstract) [张健，郝占庆，李步杭，叶吉，王绪高，姚晓琳 (2007) 长白山阔叶红松(Pinus koraiensis)林种子雨组成及其季 节动态. 生态学报, 28, 2445-2454.]

Zhang J, Hao ZQ, Song B, Li BH, Wang XG, Ye J (2009) Fine-scale species co-occurrence patterns in an old-growth temperate forest. Forest Ecology and Management, 257, 2115-2120.

Zhang J, Hao ZQ, Song B, Ye J, Li BH, Yao XL (2007) Spatial distribution patterns and associations of Pinus koraiensis and Tilia amurensis in broad-leaved Korean pine mixed forest in Changbai Mountains. Chinese Journal of Applied Ecology, 18, 1681-1687. (in Chinese with English abstract) [张健, 郝占庆, 宋波, 叶吉, 李步杭, 姚晓琳 (2007) 长白山阔叶红松林中红 松与紫椴的空间分布格局及其关联性. 应用生态学报, 18, 1681-1687.]

Zhang J, Hao ZQ, Sun IF, Song B, Ye J, Li BH, Wang XG (2009) Density dependence on tree survival in an old-growth temperate forest in northeastern China. Annals of Forest Science, 66, 204.

Zhang J, Hu JB, Lian JY, Fan ZJ, Ouyang XJ, Ye WH (2016) Seeing the forest from drones: testing the potential of lightweight drones as a tool for long-term forest monitoring. Biological Conservation, 198, 60-69.

Zhang J, Li BH, Bai XJ, Yuan ZQ, Wang XG, Ye J, Hao ZQ (2009) Composition and interannual dynamics of tree seedings in broad-leaved Korean pine (Pinus koraiensis) mixed forest in Changbai Mountain. Biodiversity Science, 17, 385-396. (in Chinese with English abstract) [张健, 李步杭, 白雪娇, 原作强, 王绪高, 叶吉, 郝占庆 (2009) 长白山阔叶红松林乔木树 种幼苗组成及其年际动态. 生物多样性, 17, 385-396.]

Zhang J, Song B, Li BH, Ye J, Wang XG, Hao ZQ (2010) Spatial patterns and associations of six congeneric species in an old-growth temperate forest. Acta Oecologica, 36, 29-38.

Zhang JL, Swenson NG, Chen SB, Liu XJ, Li ZS, Huang JH, Mi XC, Ma KP (2013) Phylogenetic beta diversity in tropical forests: implications for the roles of geographical and environmental distance. Journal of Systematics and Evolution, 51, 71-85.

Zhang L, Wang XH, Mi XC, Chen JH, Yu MJ (2011) Temporal dynamics of and effects of an ice storm on litter production in an evergreen broad-leaved forest in Gutianshan National Nature Reserve. Biodiversity Science, 19, 206-214. (in Chinese with English abstract) [张否, 王晓荷, 米湘成, 陈建华, 于明坚 (2011) 古田山常绿阔叶林调落量时间动态及冰雪灾害的影响. 生物多样性, 19, 206-214.]

Zhang LW, Mi XC, Shao HB, Ma KP (2011) Strong plant-soil associations in a heterogeneous subtropical broad-leaved forest. Plant and Soil, 347, 211-220.

Zhang M, Mi XC, Jin GZ (2014) Composition and spatial patterns of the Liangshui spruce-fir valley forest in the Xiao Hing'an Mountains. Chinese Science Bulletin, 59, 2377-2387. (in Chinese with English abstract) [张受, 米湘成, 金光泽 (2014) 小兴 安岭凉水谷地云冷杉林群落组成与空间格局. 科学通报, 59, 2377-2387.] 
Zhang N, Wang XH, Zheng ZM, Ma ZP, Yang QS, Fang XF, Xie YB (2012) Spatial heterogeneity of soil properties and its relationships with terrain factors in broad-leaved forest in Tiantong of Zhejiang Province, East China. Chinese Journal of Applied Ecology, 23, 2361-2369. (in Chinese with English abstract) [张娜, 王希华, 郑泽梅, 马遵平, 杨庆松, 方晓峰, 谢玉 涁 (2012) 浙江天童常绿阔叶林土壤的空间异质性及其与地形的关系. 应用生态学报, 23, 2361-2369.]

Zhang S, Lin F, Yuan ZQ, Kuang X, Jia SH, Wang YY, Suo YY, Fang S, Wang XG, Ye J, Hao ZQ (2015) Herb layer species abundance distribution patterns in different seasons in an old-growth temperate forest in Changbai Mountain, China. Biodiversity Science, 23, 641-648. (in Chinese with English abstract) [张姗，萄菲，原作强，匡旭，贾仕宏，王芸芸，索炎炎， 房帅，王绪高，叶吉，郝占庆 (2015) 长白山阔叶红松林草本层物种多度分布格局及其季节动态. 生物多样性，23, 641-648.]

Zhang SS, Bao YX, Wang YN, Fang PF, Ye B (2012) Activity rhythms of black muntjac (Muntiacus crinifron) revealed with infrared camera. Acta Theriologica Sinica, 32, 368-372. (in Chinese with English abstract) [章书声，鲍毅新，王艳妮，方平福， 叶彬 (2012) 基于红外相机技术的黑鹿活动节律. 兽类学报, 32, 368-372.]

Zhang SS, Bao YX, Wang YN, Fang PF, Ye B (2012) Comparisons of different camera trap placement patterns in monitoring mammal resources in Gutianshan National Nature Reserve. Chinese Journal of Ecology, 31, 2016-2022. (in Chinese with English abstract) [章书声, 鲍毅新, 王艳妮, 方平福, 叶彬 (2012) 不同相机布放模式在古田山兽类资源监测中的比较. 生态学杂志, 31, 2016-2022.]

Zhang SS, Bao YX, Wang YN, Fang PF, Ye B (2013) Estimating rodent density using infrared-triggered camera technology. Acta Ecologica Sinica, 33, 3241-3247. (in Chinese with English abstract) [章书声，鲍毅新，王艳妮，方平福，叶涁 (2013) 红外相 机技术在鼠类密度估算中的应用. 生态学报, 33, 3241-3247.]

Zhang X, Ye WH, Cao HL, Wang ZF, Shen H, Lian JY (2009) Isolation and characterization of microsatellites in Chinese white olive (Canarium album) and cross-species amplification in Canarium pimela. Conservation Genetics, 10, $1833-1835$.

Zhang Y, Jin GZ (2016) Effects of decay classes and diameter classes on physico-chemical properties of Pinus koraiensis log in a typical mixed broadleaved-Korean pine forest. Chinese Journal of Plant Ecology, 40, 1276-1288. (in Chinese with English abstract) [张瑜, 金光泽 (2016) 腐烂等级、径级对典型阔叶红松林红松倒木物理化学性质的影响. 植物生态学报, 40, 1276-1288.]

Zhang YH, Ni J, Tang FP, Pei KQ, Luo YQ, Jiang LF, Sun LF, Liang Y (2016) Root-associated fungi of Vaccinium carlesii in subtropical forests of China: intra- and inter-annual variability and impacts of human disturbances. Scientific Reports, 6, 22399.

Zhang ZC, Hao ZQ, Ye J, Lin F, Yuan ZQ, Xing DL, Shi S, Wang XG (2013) Short-term death dynamics of trees in natural secondary poplar-birch forest in Changbai Mountains of Northeast China. Chinese Journal of Applied Ecology, 24, 303-310. (in Chinese with English abstract) [张昭臣, 郝占庆, 叶吉, 落菲, 原作强, 邢丁亮, 师帅, 王绪高 (2013) 长白山次生杨桦林 树木短期死亡动态. 应用生态学报, 24, 303-310.]

Zhao AH, Du XJ, Zang J, Zhang SR, Jiao ZH (2015) Soil bacterial diversity in the Baotianman deciduous broad-leaved forest. Biodiversity Science, 23, 649-657. (in Chinese with English abstract) [赵爱花，杜晓军，喊婧，张守仁，焦志华 (2015) 宝天 曼落叶阔叶林土壤细菌多样性. 生物多样性, 23, 649-657.]

Zhao QQ, Liu HM, Mathieu J, Wang ZH, Wang XH (2014) Applicability analysis of spatially explicit model of leaflitter in evergreen broad-leaved forests. Chinese Journal of Applied Ecology, 25, 3117-3124. (in Chinese with English abstract) [赵青青, 刘何铭, Mathieu J, 王樟华, 王希华 (2014) 调落叶空间扩散模型在常绿阔叶林的适用性分析. 应用生态学报, 25, 3117-3124.]

Zhao X, Liu YY, Jin GZ (2013) Effects of topography on seedling regeneration in a mixed broadleaved-Korean pine forest in Xiaoxing'an Mountains, Northeast China. Chinese Journal of Applied Ecology, 24, 3035-3042. (in Chinese with English abstract) [赵雪, 刘妍妍, 金光泽 (2013) 地形对阔叶红松林幼苗更新的影响. 应用生态学报, 24, 3035-3042.]

Zhao X, Xu LN, Jin GZ (2015) Effect of topography on shrub regeneration in a mixed broadleaved-Korean pine forest in the Xiaoxing'an Mountains. Biodiversity Science, 23, 767-774. (in Chinese with English abstract) [赵雪, 徐丽娜, 金光泽 (2015) 地形对典型阔叶红松林灌木更新的影响. 生物多样性, 23, 767-774.]

Zhao Y, Du YJ, Cao HL, Hu XL, Ma KP (2016) Intra- and inter-specific variation on flowering and fruiting phenology in Gutianshan subtropical evergreen broad-leaved forest, Zhejiang Province. Scientia Sinica Vitae, 46, 1312-1323. (in Chinese with English abstract) [赵袁, 杜彦君, 曹洪麟, 胡小丽, 马克平 (2016) 浙江古田山亚热带常绿阔叶林开花和结实物候的种间 种内差异. 中国科学, 46, 1312-1323.]

Zhong JD, Li XK, Lü SH, Liu SY, Lu Maoxin, Chen Y, Cheng XL (2012) Studies on the stability of different communities in Nonggang karst region of Guangxi. Carsologica Sinica, 31(1), 17-22. (in Chinese with English abstract) [钟军弟, 李先琨, 吕 仕洪, 刘晟源, 陆茂新，陈燕，成夏岗 (2012) 广西弄岗喀斯特区域不同群落的稳定性评价分析. 中国岩溶, 31(1), 17-22.]

Zhou M, Liu ZL, Jin GZ (2016) Improving the accuracy of indirect methods in estimating leaf area index using three correction schemes in a Larix gmelinii plantation. Chinese Journal of Plant Ecology, 40, 574-584. (in Chinese with English abstract) [周明, 刘志理, 金光泽 (2016) 利用 3 种校正方案提高间接法测定兴安落叶松人工林叶面积指数的精度. 植物生态学报, 40, 574-584.]

Zhou YL, Qiu X, Fang XB, Yang LY, Zhao Y, Fang T, Zheng WH, Liu JS (2014) Acoustic characteristics of eight common Chinese 
anurans during the breeding season. Zoological Research, 35, 42-50.

Zhu LJ, Jin GZ, Du WX, Wang XC (2016) Characteristics of canopy disturbance for a typical broadleaf-Korean pine mixed forest in Xiaoxing'an Mountains, Liangshui, northeastern China. Journal of Beijing Forestry University, 38(6), 17-27. (in Chinese with English abstract) [朱良军, 金光泽, 杜文先, 王晓春 (2016) 小兴安岭凉水典型阔叶红松林林冠干扰特征分析. 北京林业 大学学报, 38(6), 17-27.]

Zhu LJ, Jin GZ, Wang XC (2015) Reconstruction of disturbance history of a typical broad-leaved Pinus koraiensis forest and mechanisms of disturbance occurrence. Chinese Journal of Plant Ecology, 39, 125-139. (in Chinese with English abstract) [朱良 军，金光泽，王晓春 (2015) 典型阔叶红松林干扰历史重建及干扰形成机制. 植物生态学报, 39, 125-139.]

Zhu P, Wang ZF, Ye WH, Cao HL (2013) Maintenance of genetic diversity in a small, isolated population of ancient tree Erythrophleum fordii. Journal of Systematics and Evolution, 51, 722-730.

Zhu P, Ye WH, Wang ZF, Cao HL, Zhang M, Li L, Xiao W (2009) Isolation and characterization of ten polymorphic microsatellite in the endangered tree Erythrophleum fordii Oliv. Conservation Genetics, 10, 1017-1019.

Zhu Y, Bai F, Liu HF, Li WC, Li L, Li GQ, Wang SZ, Sang WG (2011) Population distribution patterns and interspecific spatial associations in warm temperate secondary forests, Beijing. Biodiversity Science, 19, 252-259. (in Chinese with English abstract) [祝燕，白帆，刘海丰，李文超，李亮，李广起，王顺忠，桑卫国 (2011) 北京暖温带次生林种群分布格局与种间空间关联 性. 生物多样性, 19, 252-259.]

Zhu Y, Comita LS, Hubbell SP, Ma KP (2015) Conspecific and phylogenetic density-dependent survival differs across life stages in a tropical forest. Journal of Ecology, 103, 957-966.

Zhu Y, Getzin S, Wiegand T, Ren HB, Ma KP (2013) The relative importance of Janzen-Connell effects in influencing the spatial patterns at the Gutianshan subtropical forest. PLoS ONE, 8, e74560.

Zhu Y, Mi XC, Ma KP (2009) A mechanism of plant species coexistence: the negative density-dependent hypothesis. Biodiversity Science, 17, 594-604. (in Chinese with English abstract) [祝燕，米湘成，马克平 (2009) 植物群落物种共存机制: 负密度制 约假说. 生物多样性, 17, 594-604.]

Zhu Y, Mi XC, Ren HB, Ma KP (2010) Density dependence is prevalent in a heterogeneous subtropical forest. Oikos, 119, $109-119$.

Zhu Y, Zhao GF, Zhang LW, Shen GC, Mi XC, Ren HB, Yu MJ, Chen JH, Chen SW, Fang T, Ma KP (2008) Community composition and structure of Gutianshan forest dynamic plot in a mid-subtropical evergreen broad-leaved forest, east China. Journal of Plant Ecology (Chinese Version), 32, 262-273. (in Chinese with English abstract) [祝燕, 赵谷风, 张俪文, 沈国春, 米湘成, 任海保, 于明坚, 陈建华, 陈声文, 方腾, 马克平 (2008) 古田山中亚热带常绿阔叶林动态监测样地一一群落组 成与结构. 植物生态学报, 32, 262-273.]

Zou Y, Sang WG, Axmacher JC (2015) Resilience of insect assemblages to climate change in mature temperate mountain forests of NE China. Journal of Insect Conservation, 19, 1163-1172.

Zou Y, Sang WG, Hausmann A, Axmacher JC (2016) High phylogenetic diversity is preserved in species-poor high-elevation temperate moth assemblages. Scientific Reports, 6, 9116.

Zou Y, Sang WG, Wang SZ, Warren-Thomas E, Liu YH, Yu ZR, Wang CL, Axmacher JC (2015) Diversity patterns of ground beetles and understory vegetation in mature, secondary, and plantation forest regions of temperate northern China. Ecology and Evolution, 5, 531-542.

Zou Y, Sang WG, Warren-Thomas E, Axmacher JC (2016) Geometrid moth assemblages reflect high conservation value of naturally regenerated secondary forests in temperate China. Forest Ecology and Management, 374, 111-118. 
Appendix 3 Asia regional network for tropical rainforest dynamics plots

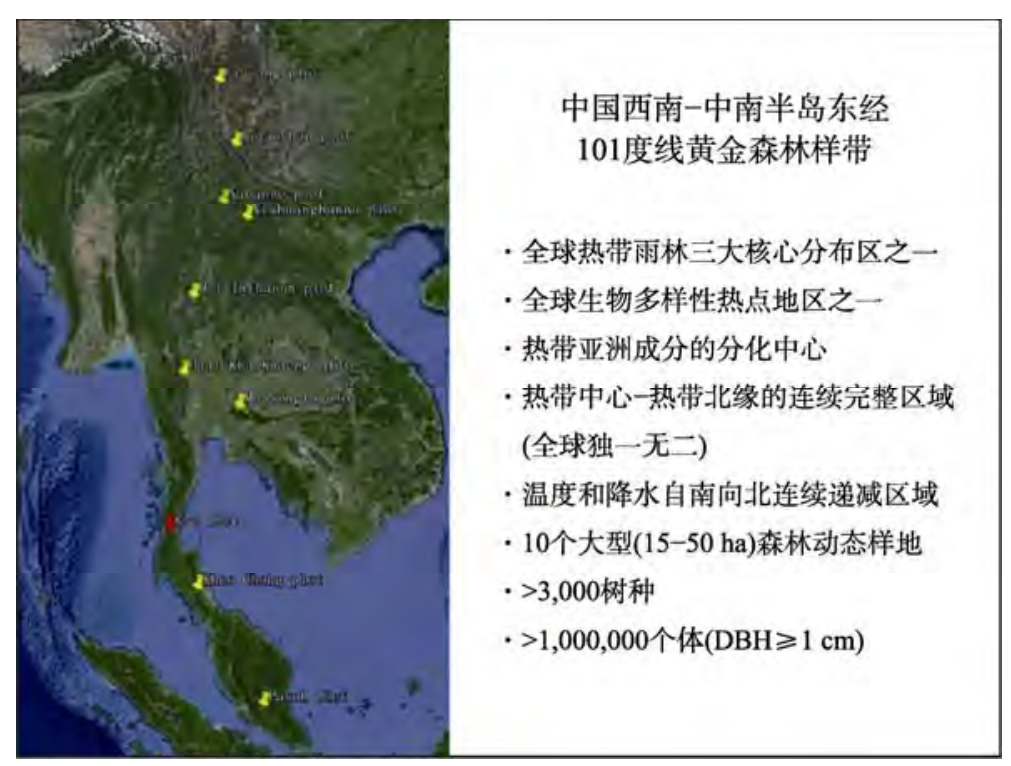




\section{参考文献}

Chen L, Zheng Y, Gao C, Mi XC, Ma KP, Wubet T, Guo LD (2017) Phylogenetic relatedness explains highly interconnected and nested symbiotic networks of woody plants and arbuscular mycorrhizal fungi in a Chinese subtropical forest. Molecular Ecology, doi: 10.1111/mec.14061

Gao C, Shi NN, Chen L, Ji NN, Wu BW, Wang YL, Xu Y, Zheng Y, Mi XC, Ma KP, Guo LD (2017) Relationships between soil fungal and woody plant assemblages differ between ridge and valley habitats in a subtropical mountain forest. New Phytologist, 213, 1874-1885.

Gao C, Shi NN, Liu YX, Peay GK, Zheng Y, Ding Q, Mi XC, Ma KP, Wubet T, Buscot F, Guo LD (2013) Host plant genus level diversity is the best predictor of ectomycorrhizal fungal diversity in a Chinese subtropical forest. Molecular Ecology, 22, 3403-3414.

Gao C, Zhang Y, Shi NN, Zheng Y, Chen L, Wubet T, Bruelheide H, Both S, Buscot F, Ding Q, Erfmeier A, Kuhn P, Nadrowski K, Scholten T, Guo LD (2015) Community assembly of ectomycorrhizal fungi along a subtropical secondary forest succession. New Phytologist, 205, 771-785.

Guo YL, Li DX, Wang B, He YL, Xiang WS, Jiang YL, Li XK (2017) Composition and spatio-temporal dynamics of litter fall in a northern tropical karst seasonal rainforest in Nonggang, Guangxi, southern China. Biodiversity Science, 25, 265-274. (in Chinese with English abstract) [郭屹立, 李冬 兴, 王斌, 何运林, 向悟生, 蒋裕良, 李先琨 (2017) 北 热带喀斯特季节性雨林调落物组分构成及时空动态. 生 物多样性, 25, 265-274.]

Han BC, Umana MN, Mi XC, Liu XJ, Chen L, Wang YQ, Liang Y, Wei W, Ma KP (2017) The role of transcriptomes linked with responses to light environment on seedling mortality in a subtropical forest, China. Ecology, doi: $10.1111 / 1365-2745.12760$

Huang H, Chen ZF, Liu DT, He GX, He RH, Li DZ, Xu K (2017) Species composition and community structure of the Yulongxueshan (Jade Dragon Snow Mountains) forest dynamics plot in the cold temperate spruce-fir forest, Southwest China. Biodiversity Science, 25, 255-264. (in Chinese with English abstract) [黄华, 陈智发, 刘德团, 和国星, 和 荣华, 李德铢, 许琨 (2017) 玉龙雪山寒温性云冷杉林动 态监测样地的物种组成及群落结构. 生物多样性, 25 ,
255-264.]

Li C, Xie F, Che J, Jiang JP (2017) Monitoring and research of amphibians and reptiles diversity in key areas of China. Biodiversity Science, 25, 246-254. (in Chinese with English abstract) [李成, 谢锋, 车静, 江建平 (2017) 中国关键地 区两栖爬行动物多样性监测与研究. 生物多样性, 25 , 246-254.]

Liu XJ, Ma KP (2015) Plant functional traits-concepts, applications and future directions. Scientia Sinica Vitae, 45, 325-339. (in Chinese with English abstract)[刘晓娟, 马克 平 (2015) 植物功能性状研究进展. 中国科学: 生命科学, 45, 325-339.]

Liu XJ, Swenson NG, Lin DM, Mi XC, Umana MN, Schmid B, Ma KP (2016) Linking individual-level functional traits to tree growth in a subtropical forest. Ecology, 97, 2396-2405.

Shen H, Cai JN, Li MJ, Chen Q, Ye WH, Wang ZF, Lian JY Song L (2017) On Chinese forest canopy biodiversity monitoring. Biodiversity Science, 25, 229-236. (in Chinese with English abstract) [沈浩, 蔡佳宁, 李萌姣, 陈青, 叶万辉, 王峥峰, 练琚愉, 宋亮 (2017) 中国森林冠层生物多样性 监测. 生物多样性, 25, 229-236.]

Xiao ZS, Li XY, Xiang ZF, Li M, Jiang XL, Zhang LB (2017) Overview of the Mammal Diversity Observation Network of Sino BON. Biodiversity Science, 25, 237-245. (in Chinese with English abstract) [肖治术, 李学友, 向左甫, 李明, 蒋 学龙, 张礼标 (2017) 中国兽类多样性监测网的建设规 划与进展生物多样性, 25, 237-245.]

Yao LJ, Yao L, Yi YM, Ai XR, Feng G, Liu JC, Lin Y, Huang W, Ding Y, Zang RG (2017) Species composition and community structure of a 6-ha subtropical evergreen and deciduous broad-leaved mixed forest plot in the Qizimei Mountains, Hubei Province. Biodiversity Science, 25, 275-284. (in Chinese with English abstract) [姚良锦, 姚兰, 易咏梅, 艾训儒, 冯广, 刘峻城, 林勇, 黄伟, 丁易, 蔵润 国 (2017) 湖北七姊妹山亚热带常绿落叶阔叶混交林的 物种组成和群落结构. 生物多样性, 25, 275-284.]

Zhang J, Hu JB, Lian JY, Fan ZJ, Ouyang XJ, Ye WH (2016) Seeing the forest from drones: testing the potential of lightweight drones as a tool for long-term forest monitoring. Biological Conservation, 198, 60-69. 